\title{
KODUSÕJA SÜNDMUSTEST ABHAASIA EESTI ASUNDUSTES 1918-21
}

\author{
Aivar Jürgenson
}

Esimene maailmasõda ja sellele järgnenud kodusõda Venemaal tõid kaasa impeeriumi lagunemise, mille tagajärjel avastasid kümned tuhanded inimesed end uue riigi territooriumilt. Muidugi polnud see üksnes endise Vene tsaaririigi elanike probleem. Euroopas tabas sarnane saatus pärast Esimese maailmasõja lõppu miljoneid inimesi. Pea iga piirinihutus tõi kaasa rahvastiku liikumisi. Eestlaste opteerumine 1920. aastate alguses Eesti Vabariigi kodakondsusse ja pea 40 ooo isiku siirdumine Eestisse on vaid üks näide paljudest. Kümned tuhanded asunikud jäid aga paigale ja pidid kohanema uute oludega.

Paljudes piirkondades eelnes Nõukogude võimu kinnistumisele mitu pingelist sõja-aastat. Enamlased võitlesid mitmel rindel Vene valgete ja piiririikide rahvuslike armeegruppidega, keda omakorda toetasid Entente' $\mathrm{i}$ liitlased. Kui Briti laevastik abistas Läänemerel nii eesti ja läti rahvusväeosi kui ka Judenitši valgekaartlasi, siis Musta mere rannikul toetasid britid oma laevastikuga grusiine ja Denikini Vabatahtlikku Armeed - ikka enamlaste vastu ja kindla sihiga aidata Venemaal võimule enamlastevastased jõud, ühtlasi üritades takistada konflikti Vene valgete ja piiririikide rahvuslaste vahel.

Eestis räägitakse tollaste sündmuste kontekstis peamiselt Vabadussõjast, sest selles kindlustas Eesti iseseisvuse, kuid eestlasi elas lisaks Eestimaale suurel hulgal - ühtekokku üle 200 ooo - ka endise Vene tsaaririigi muudes osades. On andmeid, et Siberi eesti organisatsioonid otsisid Eesti Vabariigi valitsuse kaudu kontakti Entente' iga, et liituda enamlastevastaste väeüksustega. Avaldati soovi moodustada polke, mis läheksid Eesti vägedele appi. ${ }^{1}$ Allpool näeme sarnaseid initsiatiive Taga-Kaukaasiast. Kuid elukohas puututi otseselt kokku Vene kodusõja kohalike sündmustega, nii enamlaste kui ka valgetega, mitmel pool ka valgeid toetanud brittide ja prantslastega. Kui Siberi eesti külade elanike suulises pärimuses on

\footnotetext{
1 "Kindlad teated Eesti asunikkudest Siberis ja nende vahekorrast Siberi valitsusega", Postimees, 31.07.1919, 2.
} 
tänapäevani kindlal kohal lood nii valgest kui ka punasest terrorist, siis Kaukaasias, sh Abhaasias, oli osapooli, kes oma võimu ka eestlaste asualadel kehtestada püüdsid, palju rohkem. Üldine muster oli, et kuigi neil pingelistel aastatel võimud aina vahetusid, üritasid kohalikud asunikest talupojad iga uue võimuga mingisuguselegi kompromissile jõuda - enamik asunikke ei soovinud kodukülast lahkuda. Kui kompromiss ei osutunud võimalikuks, seisti, relv käes, oma koduküla kaitsel, otsides liitu nendega, kel samad eesmärgid. Eks seegi oli omamoodi vabadussõda, kuigi suurema kodusõja kontekstis olid mastaapide erinevused tohutud.

Artiklis käsitletakse sündmuste käiku Abhaasia eesti külades Vene kodusõja ajal kuni Nõukogude võimu kinnistumiseni 1921. aastal. Allikatena kasutatud materjal on mitmekesine. Esmalt tuleks mainida käsikirjalisi tekste Eesti Ajaloomuuseumis säilitatavas Jakob Nermani kogus (fond 284) ja Eesti Kirjandusmuuseumi Kultuuriloolises Arhiivis säilitatavas Samuel Sommeri kogus (fond 235). Mõlemad kogud sisaldavad Abhaasia eestlaste käsikirjalisi mälestusi, märkmeid, kirju, kroonikaid jm. Mahukama allikana võiks nimetada Sulevi küla elaniku Villem Ludviku käsikirja ${ }^{2}$ kodusõja sündmustest Abhaasia loodeosa eesti külades Salmes ja Sulevis. Lõuna poole jäävates Suhhumi ümbruse külades toimunust pakub põhjalikuma ülevaate Kristjan Truumann. ${ }^{3}$ Diplomaatiliste ja konsulaarküsimustega seoses on artiklis kasutatud Rahvusarhiivi dokumente.

Nimetatud materjalide käibesse toomine on olnud seni lünklik. Nõukogude ajal puudusid selleks ideoloogilistel põhjustel võimalused, faktiväärtuse kaalus üles “õige” vaade teemadele. Näiteks Novosibirskis väljaantud eesti enamlaste ajalehes Siberi Teataja ilmus 1930. aastal A. Kullerkupu kirjutis ühest kodusõja episoodist, nn Sulevi lahingust Kaukaasias, ${ }^{4}$ milles kohalikke eesti partisane (nn rohelisi) esitati Nõukogude korra eest võidelnutena. Artikkel sai terava vastulöögi teises eesti enamlaste ajalehes Edasi. Autor, kes varjas end initsiaalide E. A. taha, teatas, et rohelised olid "kulaklised tegelased", talurahva jõukam kiht, kes seisis vastu nii Vene valgetele kui ka enamlastele. Roheliste eesotsas seisid autori sõnul esseerid, seega oli tegemist kontrrevolutsioonilise jõuga. ${ }^{5}$ Kontekstist ilmneb, et

\footnotetext{
2 Eesti Ajaloomuuseum (edaspidi EAM) 284.1.39: Villem Ludvig. Sulevi partisaanid. Mälestused, Sulevi partisaanide organiseerimisest, nende võitlusest, 19. märtsist 1919 kuni 19. veebruarini 1921.

3 Eesti Kirjandusmuuseumi Kultuurilooline Arhiiv (edaspidi EKLA) 235.27.14. Kr. Truumann. Punaste päevade ajalugu Estonia asunduses Suhumi ringkonnas. 1917-1921.

4 O. Kullerkupp, "Sulevi lahing ehk episood kodusõjast", Siberi Teataja, 19.01.1930.

5 E. A., "Kes olid Sulevi "rohelised" ja kellele toob kasu ajalooliste tõsiasjade võõriti käsitamine", Edasi, 05.03.1930, 2-3.
} 
nimetatud artiklid olid osa Kaukaasia eestlaste omavahelisest arveteklaarimisest, millesarnaseid tekste avaldati tollal õige ohtralt. Rõhutagem, et 1930. aastal, mil need artiklid ilmusid, oli Nõukogude Liidus alanud kollektiviseerimine ja võimud viisid klassivõitluse tähe all läbi nn kulakute väljaselgitamisi ja represseerimisi. Kuid ühes oli põhimõttelisel bolševikul E. A.-1 kindlasti õigus: ei enamik eesti asunikke ega nn rohelisi kuulunud aastatel 1918-20 enamlaste ega nende toetajate hulka.

40 aastat hiljem võttis Kaukaasia Musta mere ranniku kodusõjasündmuste käsitlemise põhjalikumalt uurida ajaloolane Lembit Võime, esmalt 1973. aastal ilmunud artiklis ${ }^{6}$ ja hiljem 198o. aastal ilmunud Abhaasia eestlasi käsitlevas monograafias. ${ }^{7}$ Nendes uurimustes väidetakse taas, et eesti asunikud võitlesid kodusõja-aastatel Nõukogude võimu eest. Võime puudutab ka eelkirjeldatud dispuuti 1930. aasta enamlikus ajakirjanduses ja asub kaitsma O. Kullerkupu seisukohta. Ta leiab, et E.A., kes käsitles nn rohelist liikumist esseerlikuna, ei olnud piisavalt kursis 1919.-20. aasta sündmustega Musta mere kubermangu lõunaosas. ${ }^{8}$ Kui Võime artikli pealkiri ütleb, et eesti asunikud võitlesid Musta mere rannikul neil saatuslikel aastatel Nõukogude võimu eest, siis järgib autor nõukogudeaegset traditsiooni kirjeldada pea kõiki Denikini-vastaseid liikumisi Kaukaasias revolutsioonilistena. ${ }^{9}$ Võime tekstist ei leia sellele aga veenvat kinnitust. Ilmselt pole ta seda soovinudki, sest möönab, et Salme asunduse koosolek kuulutas end kevadel 1918 erapooletuks, ${ }^{10}$ ja laseb mitmes seoses aimata, et tegelikult oldi pigem rahvuslikel seisukohtadel. Seda kinnitavad ka arhiivides leiduvad materjalid. Enamik tollastest eesti asunikest jälgis huviga arenguid Eestis, kohapeal seisti eelkõige oma kodude kaitsel ega soovitud ühineda ei Vene valgete ega punastega. Kuna nn roheliste küsimus on historiograafias kord juba teemaks olnud, pühendatakse ka käesolevas artiklis sellele omaette peatükk, et näidata: Musta mere ranniku nn rohelist liikumist nõukogudemeelsuses süüdistada pole mingit alust.

6 Lembit Võime, "Eesti asunikud võitluses nõukogude võimu eest Kaukaasias Musta mere rannikul (1918-1920)”, Eesti NSV Teaduste Akadeemia Toimetised. Ühiskonnateadused nr 22/4 (Tallinn: Eesti NSV TA Kirjastus, 1973), 357-379.

7 Lembit Võime, Tee uude ellu. Eesti asunduste ajaloost Kaukaasia Musta mere rannikul XIX saj. teisest poolest kuni 1929 (Tallinn: Eesti Raamat, 1980).

8 Lembit Võime, "Eesti asunikud võitluses nõukogude võimu eest...”, 358.

9 N. F. Bugai', "Predislovie", A. I. Denikin, Ocherki russkoi smutȳ (Moskva: Mõsl', 1991), 3-20 (13).

10 Lembit Võime, "Eesti asunikud võitluses nõukogude võimu eest...”, 358. 
1974. aastal ilmus tollastest sündmustest väliseestlaste Harald Kikase ja Jüri Remmelga sulest ülevaade, ${ }^{11}$ milles kasutati allikana ühtlasi Võime 1973. aasta artiklit. Arusaadavatel põhjustel ei saanud autorid kasutada rikkalikke käsikirjalisi materjale Eesti arhiivides. Artiklis rõhutatakse Võime käsitluse "bolševistlikku dialektikat ja ühekülgsust", samas leitakse, et selle abil on siiski võimalik saada ülevaade tollaste asunike poliitilistest hoiakutest ja võitlustest. ${ }^{12}$ Ka siinkirjutaja leiab, et Võime käsitlus, kuigi ajastule omases ohtras parteipoliitilises garneeringus, on vähemalt lahingu- ja muude sündmuste kirjeldamisel üldiselt faktitäpne.

Lisateavet kodusõja sündmuste kohta Kaukaasias ja eestlaste rollist nendes annavad teated, mis ilmusid tolle pöördelise perioodi Eesti ajakirjanduses. Avarama pildi loomiseks on käesolevas artiklis kasutatud ka kirjandust Gruusia, Abhaasia jt autorite sulest.

Ühtlasi näidatakse artiklis, missugust rolli mängis Eesti Vabariigi väljakuulutamine asunike jaoks - kuidas see tähendas asukohamaal sisemigrandist välismigrandiks muutumist, aga ka uusi poliitilisi võimalusi. Samas näidatakse, kui keeruline oli ennast positsioneerida ja otsuseid langetada olukorras, kus rindejooned pidevalt nihkusid, kus kehtestati erinevaid neutraaltsoone ja tuli arvestada mitmesuguste võimudega ning vastu seista kõikvõimalikele marodööritsevatele salkadele.

\section{Poliitilised arengud Taga-Kaukaasias aastatel 1917-18}

Ajal, mil eesti külad Abhaasias 188o. aastatel rajati, ei olnud Abhaasiat administratiivse üksusena maakaardil - Abhaasia vürstiriigi likvideerisid tsaarivõimud pärast Kaukaasia sõja lõppu 1864. aastal ning jaotasid selle territooriumi kahe tsaaririigi kubermangu vahel. Abhaasia tuumikalad liideti Suhhumi sõjaväelise ringkonna nime all Kutaisi kindralkubermanguga (alates 1883. aastast Suhhumi ringkond Kutaisi kubermangu koosseisus, alates 1903. aastast oli ringkond Tiflisis resideerunud Kaukaasia asehalduri otsealluvuses). Abhaasia väiksem loodeosa liideti 1866. aastal moodustatud Musta mere ringkonnaga Kubani kubermangus (aastatel 1896-1918 eksisteeris eraldi Musta mere kubermang ja selle Sotši ringkond). 1904. aasta detsembris eraldati tsaar Nikolai II sugulase Aleksandr P. Oldenburgski initsiatiivil Suhhumi ringkonnast Gagra piirkond ning liideti Musta mere

$11 \quad$ Harald Kikas, Jüri Remmelgas, "Kaukaasia Eesti asundused Vene kodusõja keerises”, Verbum habet Sakala! (New York, Stokholm, Toronto: Korp! Sakala, 1974), 85-93. 12 Ibid., 85. 


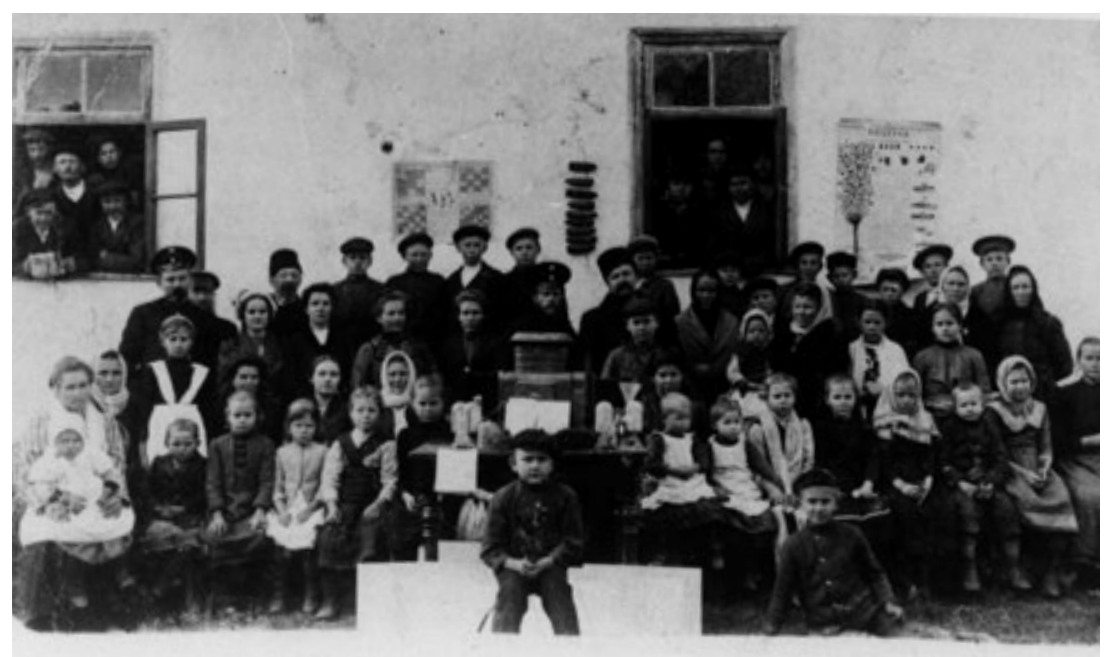

Joonis 1. Salme põllumajanduse kursusest osavõtjad, 1914. RA, EFA.331.o.161168

kubermangu Sotši ringkonnaga. ${ }^{13}$ Seega asusid eestlaste Alam- ja ÜlemLinda ning Estonia külad Kutaisi kubermangu Suhhumi ringkonnas, Salme ja Sulevi külad Musta mere kubermangu Sotši ringkonnas. Piir kahe kubermangu vahel jooksis mööda Bzõbi jõge. Piir mõjutas ka asunike kujunevat paikkondlikku identiteeti. Kuna Abhaasiat administratiivse üksusena ei eksisteerinud, ei kasutatud tollal veel eesti asunike tähistamiseks terminit "Abhaasia eestlased". Abhaasia lõunapoolsete eesti asunduste elanikke kutsuti "Suhhumi eestlasteks", põhjapoolsete omasid "Sotši eestlasteks". ${ }^{14}$

Veebruarirevolutsiooni järel võimule tulnud Venemaa Ajutine Valitsus kaotas ametlikult senise Kaukaasia asehalduri institutsiooni, mis asendati erikomiteedega. Suhhumi ringkonna komitee moodustati 10. märtsil 1917, seda juhtis Abhaasi vürstisoost Aleksander Šervašidze. ${ }^{15}$ Bolševike võimuhaaramisele Petrogradis oktoobris 1917 reageerisid Taga-Kaukaasia

13 Jemal Gamakharia, "Abkhazia/Georgia: Historical and Political Problems", Problems on History, Politics and Culture of Abkhazia, ed. by Jemal Gamakharia, Lia Akhaladze (Tbilisi: Levan Titmeria, 2016), 9-63 (37); Teĭmuraz A. Achugba, Istoriya Abhazii v datah (Suhum, 2011), 91; Zurab Papaskiri, O natsional'no-gosudarstvennom oblike Abhazii/Gruziya (Tbilisi: Vsegruzinskoe istoricheskoe obshchestvo im. Ékvtili Takashvili. Abhazskaya organisatsiya, 2003), 51; Dali Nikolaishvili, Revaz Tolordava, Davit Sartania, Lali Kutateladze, "Problems with the Drawing a State Border along the River Psou Section", Earth Sciences, 4 (2015), 60-67 (65).

$14 \quad$ Nt M. J. Wunk, "Mälestused Suhumist", Postimees, 14.05.1914, 7.

15 Gamakharia, "Abkhazia/Georgia: Historical and Political Problems”, 39. 
kubermangude ja ringkondade juhid Taga-Kaukaasia Komissariaadi, sisuliselt piirkonna valitsuse moodustamisega. Enamlaste võimu ei tunnustatud ja komissariaati neid ei kaasatud. 7. detsembril 1917 tühistas komissariaat Gagra piirkonna eraldamisotsuse aastast 1904 ja taasliitmise Suhhumi ringkonnaga ${ }^{16}$ Seega pidanuksid ka eestlaste Salme ja Sulevi külad minema Suhhumi ringkonna koosseisu. Vene enamlased ega valged seda otsust aga ei aktsepteerinud, opereerides endiselt tsaariaegse piiriga Bzõbi jõel. Edasistes sündmustes tähendas see mittetunnustamine eesti küladele pidevat võimude vahetumist ja vajadust nende vahel laveerida ning kohati ka, relv käes, oma kodusid kaitsta. Missugused need jõud olid, kellega kohalikel eestlastel tuli kokku puutuda?

Esmalt enamlased, kes olid Taga-Kaukaasia Komissariaadist välja jäetud ja seega ei pidanud vajalikuks tunnustada ka selle otsuseid. Enamlaste vastukäik oli keelduda kaasamast komissariaadi esindajaid rahukõnelustesse bolševistliku Venemaa ja Keskriikide vahel Brest-Litovskis. ${ }^{17}$ Kui BrestLitovskis 3. märtsil 1918 sõlmitud rahuleping nägi ette ulatuslike Taga-Kaukaasia territooriumide loovutamise Osmani impeeriumi mõjusfääri, ${ }^{18}$ polnud Taga-Kaukaasia poliitikud sellega loomulikult nõus. Kuna bolševistlik Venemaa oli nad maha müünud, otsustati enamlastest veelgi selgemalt distantseeruda ja 1918. aasta aprilli lõpus kuulutati sõltumatu riigina välja TagaKaukaasia Demokraatlik Föderatiivne Vabariik. Peab küll lisama, et selle eluiga jäi lühikeseks - ammuse vaenu tõttu kohalike rahvaste vahel pidas see vastu vaid ühe kuu. Selle osadest moodustatud rahvusriigid hakkasid omaette valmistuma enamlaste võimuambitsioonide vastu piirkonnas, monarhiale ustavaks jäänud vägede pealetungi vastu põhjas ja osmanite vastu lõunas. ${ }^{19}$ Kuna osmanid olid viinud oma väed juba Armeeniasse ja Aserbaidžaani, kutsusid grusiinid mais oma territooriumile sakslased, et Türgi mõju tasakaalustada. 28. mail 1918 sõlmitud Poti leping, mille alusel toodi Potisse Gruusias ja Otšamtšõrasse Abhaasias 30oo-meheline Saksa korpus, tähendas mõnede autorite hinnangul sisuliselt Gruusia langemist Saksamaa protektoraadi alla. Enamlased, kes ei tunnustanud Gruusia iseseisvust, käsitasid sakslaste tulekut okupatsioonina. ${ }^{20}$ Lepingu sõlmimist

$16 \quad$ Ibid., 41; G. R. Marhuliya, “"Krasnaya” i "belaya” Rossiya protiv nezavisimosti Gruzii (1918g.)”, Istoricheskie Razȳskaniya. Ezhegodnik nauchnȳh trudov Abhazskő̆ organizatsii Vsegruzinskogo istoricheskogo obshchestva im. Ekvtimé Takaishvili: zhurnal, 3 (2000), 113-121 (113).

17 Charles King, Vabaduse viirastus. Kaukaasia ajalugu (Tallinn: Tänapäev, 2012), 171.

18 David Bullock, Vene kodusõda 1918-1922 (Tallinn: Koolibri, 2010), 104.

19 King, Vabaduse viirastus, 171; John Keegan, Esimene maailmasõda (Tallinn: Varrak, 2002), 373 .

20 Marhuliya, ““"Krasnaya” i “belaya” Rossiya protiv nezavisimosti Gruzii (1918g.)”, 115. 
on kohati põhjendatud ka Gruusia menševike ajalooliste sidemetega Saksa sotsialistidega, mis olevat kallutanud Gruusia menševikke toetuma pigem Saksamaale kui Entente'ile. ${ }^{21}$ Saksamaa, kes tunnustas Gruusiat de facto, kavatses grusiine kasutada võitluses Entente'iga. Gruusiasse toodi mehi ka Balkani rindelt, Saksa instruktorid asusid välja õpetama Gruusia armeed, et kasutada seda inglaste väljatõrjumisel Kaukaasiast. Sihikul olid Bakuu naftaväljad. Poti sadam renditi 60 aastaks Saksamaale. ${ }^{22}$

Kuigi ka Aserbaidžaanis ja Armeenias olid võimul sotsialistlikud parteid ja näiteks Eestis domineeris 1919. aasta Asutava Kogu valimistel tugev pahempoolsus, ${ }^{23}$ siis Gruusias koondus võim valdavalt ühe jõu, pikaajalise revolutsioonilise võitluse kogemusega menševike kätte. Gruusia esimestel üldise valimisõigusega parlamendivalimistel 1919. aasta jaanuaris said menševikud 130 parlamendikohast tervelt 109. ${ }^{24}$ Arusaadavalt moodustasid nad valitsuse - vaid üks selle liige oli mitte-menševik. ${ }^{25}$ Vastusena riigi mõnes osas puhkenud talurahvamässudele viis Gruusia menševike valitsus läbi ulatusliku maareformi. ${ }^{26}$ See pidi aitama neutraliseerida enamlaste mõju ja samas kallutama rahvast ühtse Venemaa eest seisvate Vene valgete vastu.

Vene valgete näol oli tegemist väga eripalgelise seltskonnaga, keda ühendas soov võidelda enamlaste vastu. See ajendas neid toetuma Entente'ile, mis lubas neil aidata bolševismi purustada. Saksamaad ei usaldatud, sest usuti, et enamlased on keiserliku Saksamaa käsilased. ${ }^{27}$ Kaukaasia kontekstis tuleb valgekaartlastest mainida eelkõige Vabatahtlikku Armeed, kelle juhataja Anton Denikin toetus üheselt Entente'ile ja samas tõrkus tunnustamast senisest tsaaririigist lahku löönud ja end äsja iseseisvaks kuulutanud riike, sh Gruusiat. Denikini sõnastatud eesmärki - "ühtne ja jagamatu Venemaa" - toetasid ka teised valgete juhid. ${ }^{28}$

Entente'iga seoses tuleb rääkida eelkõige brittidest. Enamlaste pööre novembris 1917 oli sillutanud teed Venemaa sõjast väljumisele. See tähendas, et Keskriigid võisid hakata nüüd vägesid idast läände üle viima.

\footnotetext{
${ }^{21}$ Jonathan D. Smele, The Russian civil wars 1916-1926. Ten years that shook the world (London: Oxford University Press, 2015), 43.

22 Anton I. Denikin, Ocherki russkoi smutȳ (Moskva: Mȳslj, 1991), 139.

23 Sotsiaaldemokraadid, Tööerakond ja sotsialistid-revolutsionäärid võitsid 2/3 kõigist rahvaesinduse kohtadest. Vt Enn Tarvel, Eesti rahva lugu (Tallinn: Varrak, 2018), 214.

24 Menševikele antud häälte koguhulk oli 640 ooo, bolševikele anti 24 ooo häält. Bolševikud ei saanud parlamendis ainsatki kohta. Vt Robert Conquest, Am Anfang starb Genosse Kirow. Säuberungen unter Stalin (Düsseldorf: Droste Verlag, 1970), 301.

25 Denikin, Ocherki russkoi smut $\bar{y}, 179$.

26 King, Vabaduse viirastus, 172, 174.

27 Bullock, Vene kodusõda 1918-1922, 22.

28 Ibid., 23.
} 
Loomulikult ei meeldinud see Entente'ile, mis üritas idarinnet taastada. Oli oluline, et Keskriigid ei pääseks ligi ressurssidele Kaukaasias, eelkõige Bakuu naftaväljadele. Detsembris 1917 jaotasid Suurbritannia ja Prantsusmaa Lõuna-Venemaa omavahel huvi- ja majandussfäärideks: Prantsusmaale jäi Ukraina, Suurbritanniale aga Musta mere idasadamad koos Taga-Kaukaasia ja Kaspia mere rannikuga. ${ }^{29}$ Briti kindralmajor Lionel Dunsterville'ile anti käsk rajada Taga-Kaukaasias sõjaväeline missioon. ${ }^{30}$

Niisiis mängisid 1918. aastal Taga-Kaukaasias sõjalist ja poliitilist rolli lisaks kohalikele ka muud jõud - Vene enamlased ja valged, sakslased liidus türklastega ning britid. Sügisel väljus sõjast esmalt Türgi ja novembris ka Saksamaa. Nüüd hakkas Gruusia valitsus tuge otsima Suurbritannialt, kes pikendas oma mandaati piirkonnas selleks, et tagada relvarahu tingimuste täitmine nii osmanite kui ka sakslastega. ${ }^{31}$ Brittide poliitika TagaKaukaasias oli muidugi osa laiemast tegevusest endise Vene impeeriumi territooriumidel, mis nägi ette toetada uusi enamlastevastaseid võime nii piirirahvaid kui ka Vene valgeid. Kui Baltikumis tähendas see eestlasi, lätlasi ja Judenitši Loodearmeed, siis Taga-Kaukaasias sealseid rahvaid ja Denikini Vabatahtlikku Armeed. Eestisse saabus Briti eskaader 1918. aasta lõpul, Gruusiasse ja Abhaasiasse 1919. aasta algul. Nii Balti provintsidesse kui ka Taga-Kaukaasiasse saatis Inglismaa ka oma sõjalise missiooni. Eestis juhtis seda kolonelleitnant Stephen George Tallents, ${ }^{32}$ Taga-Kaukaasias kindralleitnant Charles James Briggs, kes 1919. aasta kevadel loovutas juhatamise kindralmajor Herbert Holmanile. ${ }^{33}$ Toetades Gruusia ja Abhaasia kohalikke jõude võitluses enamlastega, üritasid britid samal ajal reguleerida sõjalist konflikti Gruusia armee ja Denikini armee valgete vahel.

\section{Arengud Abhaasias 1917-18}

Abhaasia puhul ei saa mööda minna ka kohalikust jõust - abhaasidest. 8 . novembril 1917 toimunud Abhaasi Rahva Kongressil moodustati Abhaasi Rahva Nõukogu - autonoomne võimukeskus, mille peamisi sihte oli abhaasi rahva enesemääramine. Nõukogu ei olnud ühtne ei poliitiliste vaadete ega ka tulevikuplaanide poolest: üks osa abhaasi poliitikutest soovis ühendada

29 Bullock, Vene kodusõda 1918-1922, 91, 102; Keegan, Esimene maailmasõda, 373.

30 King, Vabaduse viirastus, 177; Bullock, Vene kodusõda 1918-1922, 104; Smele, The Russian civil wars 1916-1926, 43.

31 King, Vabaduse viirastus, 173.

32 Magnus Ilmjärv, "Balti-küsimus Pariisi rahukonverentsi eel ja ajal 1918-1920", Acta Historica Tallinnensia, 25 (2019), 131.

33 Bullock, Vene kodusõda 1918-1922, 105. 
Abhaasia loodava Põhja-Kaukaasia mägirahvaste riigiga, teine osa eelistas liitlassuhteid Gruusiaga. 9. veebruaril 1918 sõlmiti Tiflisis Abhaasi Rahva Nõukogu ja Gruusia Rahvusnõukogu vahel heanaaberlike suhete leping. Abhaaside huvid koostöö vastu grusiinidega seostusid eelkõige enamlaste ohuga. Oht oli reaalne, sest juba nädal pärast lepingu sõlmimist haarasid enamlased Suhhumis võimu. 17. veebruaril nõudis Abhaasi Rahva Nõukogu ultimatiivselt enamlaste sõjarevolutsioonikomitee likvideerimist. Grusiinide abiga sunniti enamlased taanduma. 8. aprillil 1918 järgnes uus enamlaste võimuhaaramine Suhhumis. Aprilli lõpus ja mai algul toimusid lahingud ka Suhhumi-lähedaste eesti külade juures. ${ }^{34}$ 17. mail sundisid gruusia menševikud, kes omakorda said abi sakslastelt, enamlased Suhhumist uuesti lahkuma. ${ }^{35}$

Maapiirkondades võis võim sel keerulisel ajal käia käest-kätte veel sagedamini. Abhaasia ajaloolane Soslan Salakaja on analüüsinud tollest ajast pärinevaid kirjalikke mälestusi. Ilmneb, et üsna sageli meenutatakse pidevaid võimuvahetusi - kuidas väiksemates asulates piisas paarikümnest mehest, et kehtestada teab mitmendat korda Nõukogude võim, mis siis järgmise mõnekümnemehelise salga poolt jälle kukutati. ${ }^{36}$ Eestlaste külades Salmes ja Sulevis kestis enamlaste esimene võimuperiood veebruari algusest juuni keskpaigani 1918, misjärel Gruusia väed enamlased välja ajasid. Enamlaste tollast võimuperioodi on sealsed eestlased kirjeldanud suhteliselt rahulikuna, millele viitab kasvõi see, et samal ajal viibis Sulevis tuntud eesti asunduste aktivist Samuel Sommer, kes oli juba tsaariajal teinud asundustes rahvuslikku organiseerimistöö $\mathrm{d}^{37}$ ja avas nüüd 1918. aasta maikuus Sulevis kultuur-hariduslikud kursused. Samuti organiseeris ta 15. mail eesti haridusseltsi. ${ }^{38}$ Materjalidest ei ilmne, et punavõimud seda takistanud oleksid, kuid peab arvestama asjaoluga, et enamlastel polnud aega ega ressurssi kohaliku tasandi võimu juurteni ümber kujundada. Näiteks sealsamas Sulevis oli alates 1918. aasta algusest külavanemaks Villem Ludvik, kellest siis, kui enamlased veebruaris saabusid, sai kohaliku külanõukogu (sellesse kuulus Sulevi küla koos Salmega) täidesaatva komitee esimehe abi Sulevis. Sisuliselt säilitas ta külavanema positsiooni. Olgu öeldud,

34 EKLA 235.30.14, 1. 190: J. Tammann. Tähtsamad juhtumised Suhumis (Abhasias). 11.04.1921.

35 Oleg H. Bgazhba, Stanislav. Z. Lakoba, Istoriya Abhazii s drevneı̌shih vremen do nashih dně (Suhum: Ministerstvo obrazovaniya i nauki RA, 2015), 300-301.

36 Dr Soslan Salakaja suulised teated autorile.

37 Vt Aivar Jürgenson, "Virumaa kooliõpetajast koduloolane August Martin ja Kaukaasia eestlased”, Mäetagused, 66 (2017), 37.

38 EAM 284.1.39, 1. 18: Villem Ludvig. Sulevi partisaanid. Mälestused Sulevi partisaanide organiseerimisest, nende võitlusest, 19. märtsist 1919 kuni 19. veebruarini 1921. 
et kui Gruusia sõjavägi enamlased juunis minema kihutas, jäi senine külavalitsus Sulevis paika, komissariks ikka seesama Villem Ludvik. ${ }^{39}$ Seega võimud küll vahetusid, kuid omavalitsuse tasandil sõja tingimustes suuri muutusi ei toimunud. Villem Ludvikust teame, et enamlaste kaasajooksik ta igatahes ei olnud, kuigi teatud laveerimisoskust külavanema positsiooni säilitamine erinevate võimude ajal kindlasti eeldas. Eesti asunduste aktivist Jakob Lukats kirjutab, et mõnikümmend eesti meest astus enamlaste sõjaväkke, kellega käidi maad rüüstamas. Mõned saanud koguni komissarideks. "Mõistlikumad asunikud" seisnud aga selgelt punastele vastu. Samuti meenutab Lukats, et punased rekvireerisid vilja, kariloomi ja hobuseid. ${ }^{40}$ Eesti asunduste historiograafias teame Lukatsit tuntud liialdajana. Kohati pidid ka asunikud ise tema liialdusi eesti ajakirjanduses ümber lükkama. ${ }^{41}$ Vaevalt et enamlaste väkke siirdunute hulk mõnekümneni ulatus. Muud säilinud allikad igatahes ei näita 1918. aastal Salme ja Sulevi elanike hulgas mingit märkimisväärset toetust enamlastele.

Kui Sotšist tuli enamlaste mobilisatsioonikäsk, kuulutasid Salme ja Sulevi end Venemaa sündmuste suhtes neutraalseks, põhjendusega, et külade elanikud on Eesti Vabariigi kodanikud. Kohalikud mehed jäetudki rahule. ${ }^{42}$ Mille alusel end Eesti Vabariigi kodanikeks kuulutati, pole teada. Maanõukogu kodakondsust reguleeriv määruski jõustus alles 4. detsembril 1918. Ilmselt toetusid Salme ja Sulevi eestlased 1918. aasta kevadel-suvel end Eesti Vabariigi kodanikeks nimetades Eesti Vabariigi väljakuulutamise faktile. Teadmine vabariigi väljakuulutamisest oli jõudnud üle endise tsaaririigi asuvatesse eesti asundustesse eestikeelse, kuid veel enam kohaliku vene ajakirjanduse vahendusel.

Suhhumi ringkonnas asuva Estonia küla elust enamlaste võimu all 1918. aasta kevadel kõnelevad külaelanik Kristjan (Christjan) Truumanni mälestused. Ta kirjutab, et üks osa küla meestest läks enamlaste mobilisatsiooniga veebruaris 1918 kaasa - neile jagatud Suhhumis endisest sõjaväe laost püssid "pursuide valitsuse" vastu võitlemiseks. Samas kasutasid lõuna poolt Suhhumile lähenevad Gruusia menševike üksused Estonia küla mehi teejuhtidena. ${ }^{43}$ Enamlaste poolel võidelnud estonialased nõudnud ka oma

\footnotetext{
$39 \quad$ Ibid., 1. 21.

40 Jakob Lukats, “Keset ilmakära. Eesti asunikkude elu Gruusias”, Postimees, 09.07.1921,

5.

41 Asunik, "Eksitused artiklis "Keset ilmakära."”, Postimees, 30.07.1921, 7.

42 EKLA 235.29.6, l. 1: Lühikene ülevaade poliitiliste liikumiste kohta Sotshi ringkonnas Mustamere kubermangus 1918-st kuni 1921 aasta veebruari kuuni.

43 EKLA 235.27.14, 1. 4-5: Kr. Truumann. Punaste päevade ajalugu Estonia asunduses Suhumi ringkonnas. 1917-1921.
} 
kodukülas enamliku korra kehtestamist, 4. aprillil loetud külakoosolekul ette Suhhumi revolutsioonikomitee dekreet, mille kohaselt pidi iga küla valima endale enamlasest komissari. Estonias tekitanud see pahameelt, ${ }^{44}$ kuid nagu eelnevast teame, ajasid Gruusia menševikud sakslaste abiga enamlased mai keskel piirkonnast välja ja nii ei saanud Nõukogude võim Estonias kinnistuda. Põhja pool, sh eestlaste Salmes ja Sulevis püsis enamlaste võim küll juunini, kuid siis taandus Gruusia armee survel ka sealt.

\section{Gruusia võimu kehtestamine Abhaasias}

Grusiinide pealetungi ja võimu kindlustamist Abhaasias 1918. aasta kevadel-suvel mõjutasid mitmed arengud grusiinide ja abhaaside omavahelistes suhetes. Peab silmas pidama, et 9. veebruaril 1918 sõlmitud leping Abhaasi Rahva Nõukogu ja Gruusia Rahvusnõukogu vahel oli leping kahe organisatsiooni, mitte kahe riigi vahel - iseseisvat Gruusiat ja Abhaasiat polnud veel välja kuulutatud. 11.-26. mail 1918 toimus Batumis rahukonverents, mis pidi reguleerima suhteid regioonis ja millest võtsid osa ühelt poolt liitlased Esimeses maailmasõjas, Türgi ja Saksamaa, teisalt kohalikud jõud - vastloodud Taga-Kaukaasia Demokraatlik Föderatiivne Vabariik (mille koosseisus oli ka Gruusia) ning Ühendatud Kaukaasia Mägilaste Liit. Konverentsi avapäeval 11. mail arutati Mägilaste Liidu initsiatiivil Põhja-Kaukaasia mägilaste riigi loomise küsimust ning kuulutati see välja Mägivabariigi nime all. Mägivabariigi koosseisu kuulusid Dagestan, Tšetšeenia-Ingušeetia, Osseetia, Karatšai-Balkaaria, Kabarda, Abhaasia ja Adõgee. Riik teatas väljaastumisest Nõukogude Venemaa koosseisust. 11. maid loevad Abhaasia ajaloolased Abhaasia riikluse taastamise päevaks - selle oli 1864. aastal likvideerinud Vene tsaarivõim. Kuupäeva peetakse oluliseks ka edasiste sündmuste kontekstis: nimelt kuulutati Gruusia Demokraatlik Vabariik välja hiljem, 26. mail, st kaks nädalat pärast Mägivabariiki. Oluline on märkida, et Mägivabariigi väljakuulutamisele järgnes kohe ka Türgi poliitiline tunnustus. ${ }^{45}$ Saksamaalt kui Gruusia toetajalt Mägivabariik tunnustust aga ei saanud - Saksamaa esindaja Batumi rahukonverentsil kindral Otto von Lossowi arvamuse kohaselt oleks Abhaasia pidanud kuuluma Gruusia koosseisu. ${ }^{46}$

\footnotetext{
$44 \quad$ Ibid., 1. 6.

45 Bgazhba, Lakoba, Istoriya Abhazii s drevněshih vremen do nashih dne ̌, 311-312; Achugba, Istoriya Abhazii v datah, 99.

${ }^{46}$ Jemal Gamakharia, "Abkhazia as the part of the democratic republic of Georgia", Abkhazia: Essays from the History of Georgia: from ancient days till present days, ed. by Jemal Gamakharia (Tbilisi: Ministry of Education and Culture of Abkhazia, 2011), 391.
} 
Gruusia Demokraatliku Vabariigi ja Abhaasia riiklust esindava Abhaasi Rahva Nõukogu vahekord oli vaatamata eriarvamustele esialgu siiski konstruktiivne, kuna abhaasid nägid grusiinides liitlast bolševike vastu. 11. juunil 1918 sõlmiti nende vahel koostööleping ${ }^{47}$ mille alusel saabusid Abhaasiasse kindral Giorgi Maznijevi (enne nime venestamist Mazniašvili) üksused, kes tõrjusid sakslaste abiga enamlased Abhaasiast välja ja tungisid edasi Põhja-Kaukaasiasse. ${ }^{48}$ Nüüd läks olukord abhaaside jaoks kontrolli alt välja. Maznijev kuulutati 18. juunil Gruusia sõjaministri korraldusel Abhaasia kindralkuberneriks, 23. juunil moodustati Abhaasia territooriumil kindralkubermang. Abhaasi Rahva Nõukogu ega Mägivabariigi protestidest Gruusiale ja Saksamaale välja ei tehtud..$^{49}$ Viimasel polnud ka reaalset jõudu Abhaasia abistamiseks.

Gruusia otsusekindlust Abhaasias mõjutas ühelt poolt Saksamaa toetus, teiselt poolt Gruusia vägede edu rinnetel. Nende edasitungimine põhja suunas oli võrdlemisi kiire, enamlased ei suutnud neile vastupanu osutada, sest teiselt poolt ründasid neid Vene valgekaartlased. 3. juulil hõivasid grusiinid Gagra ja Adleri, 5. juulil Sotši. Järjestikuste võidukate lahingute järel jõuti 27. juulil Tuapsesse. ${ }^{50}$ Septembriks olid Gruusia väed okupeerinud kogu Sotši ringkonna. Positsioonide kindlustamist Tuapses põhjendati väitega, et muistse Gruusia kuningriigi piir oli 13. sajandil jooksnud just sealt. ${ }^{51}$

15. augustil süüdistasid Gruusia okupatsioonivõimud Abhaasi Rahva Nõukogu Mägivabariigi orientatsiooniga liikmeid türgimeelsuses ning mässulised liikmed asendati gruusiameelsetega. ${ }^{52}$ Kui selgus, et Abhaasi Rahva Nõukogu liikmed pidasid läbirääkimisi ka Vene valgetega, saatsid Gruusia võimud 10. oktoobril Abhaasi Rahva Nõukogu hoopis laiali. Mõned selle saadikud arreteeriti ja toimetati Tiflissi. ${ }^{53}$ Võimuhaaramine ja sellega kaasnenud repressioonid abhaaside vastu tekitasid küsimusi ka rahvusvaheliselt, iseäranis nüüd, kui seni grusiine toetanud Saksamaa viis sügisel 1918 pärast Saksamaal puhkenud revolutsiooni oma väed Kaukaasiast

$47 \quad$ Viacheslav A. Chirikba, The international legal status of the Republic of Abkhazia (Sukhum: Ministry of Foreign Affairs of the Republic of Abkhazia, 2014), 46.

48 Vt RA, ERA.1583.1.294, slaid 42: Kirjavahetus Briti välisministeeriumi ja isikutega Taga-Kaukaasias elunevate eestlastega kontakti loomise asjus. 11.02.1920-10.11.1920. Pagineerimata.

49 Bgazhba, Lakoba, Istoriya Abhazii s drevně̌shih vremen do nashih dne, 322.

50 Tänapäeval linn Vene Föderatsiooni Krasnodari krais.

51 Marhuliya, “"Krasnaya” i "belaya” Rossiya protiv nezavisimosti Gruzii (1918g.)”, 120.

52 Bgazhba, Lakoba, Istoriya Abhazii s drevne ̌shih vremen do nashih dne ̌̆, 320-322, 327.

53 Stanislav Lakoba, "Abhaziya - Gruziya: 1918-1921 gg. “...ne mozhet vmeshivat'sya

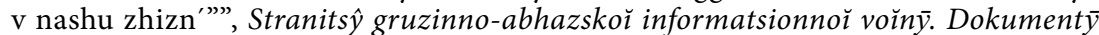
$i$ materialy. Tom II. Sost. T. A. Achugba, D. T. Achugba (Suhum: AbIGI, 2015), 234; Bgazhba, Lakoba, Istoriya Abhazii s drevneǔshih vremen do nashih dne , 321-322, 327, 336. 
välja. Nende positsiooni regioonis sisse võtnud brittide toetus Gruusia menševike valitsusele ei olnud nii innukas kui sakslaste oma. Nagu teatas tollane Briti sõja- ja lennuväeminister Winston Churchill, ei olnud britid Kaukaasias selleks, et kaitsta väikeseid riike Venemaa vastu. ${ }^{54}$ Britid toetasid regioonis peamiselt Anton Denikinit, kes soovis Venemaa tsaariaegsete piiride taastamist. Grusiinide okupatsiooni suhtes Abhaasias võtsid britid kriitilise hoiaku. 5. detsembril 1918 pöördus Briti kindral Thomson Gruusia valitsuse poole arreteeritud abhaasia poliitikute küsimuses, kelle vangistuses pidamist ei peetud õigustatuks. ${ }^{55}$

Selleks, et jätta mulje anneksiooni legitiimsusest Abhaasias, kuulutasid Gruusia võimud 13. veebruariks 1919 välja uued Abhaasi Rahva Nõukogu valimised. Abhaasia ja Gruusia ajaloolaste hinnangud neile valimistele erinevad tänaseni. Abhaasia ajaloolase Stanislav Lakoba meelest ei olnud need valimised demokraatlikud, sest osa senise Abhaasi Rahva Nõukogu abhaasidest saadikutest olid teatavasti arreteeritud ega saanud valimisteks valmistuda. Lakoba toob esile, et ka kevadel 1919 olukorda Musta mere ääres reguleerida üritanud britid ei hinnanud valimisi demokraatlikeks. ${ }^{56}$ Gruusia autor Jemal Gamakharia küll möönab arreteerimiste fakti, kuid peab valimisi siiski õiguspärasteks. ${ }^{57}$ Gamakharia väidet kritiseerinud grupp Saksa ajaloolasi leiab, et valimised, mis toimusid menševike poolt sõjaliselt okupeeritud Abhaasias, teenisid valitsevate võimude legitimatsiooni eesmärki. ${ }^{58}$

Igatahes ei olnud tegemist valimistega sõltumatus Abhaasias - ka Gamakharia möönab, et Abhaasi Rahva Nõukogu valimiste reglementi ei kinnitatud mitte Abhaasias, vaid seda tegi 27. detsembril 1918 Gruusia parlament. Kui esialgu oli Abhaasi Rahva Nõukogu olnud abhaaside õiguslik instrument, siis nüüdse reglemendi kohaselt oli valimistel õigus osaleda kõigil Abhaasia elanikel, kes olid vanemad kui 20 aastat ja asunud Abhaasias enne 19. juulit 1914 (st enne Esimest maailmasõda). ${ }^{59}$ Seega hõlmas see ka isikuid, kes olid Abhaasiasse jõudnud viimastel kümnenditel massikolonisatsiooni käigus ja sealset demograafilist olukorda oluliselt muutnud.

\footnotetext{
$54 \quad$ King, Vabaduse viirastus, 180.

55 Bgazhba, Lakoba, Istoriya Abhazii s drevneı̌shih vremen do nashih dně̆, 340.

56 Stanislav Z. Lakoba, "Ob issledovanii nemetskih uchenȳh i nekotorȳh aspektah politicheskoŭ istorii Abhazii 2o-h gg. XX v.", Vestnik Akademii Nauk Abhazii 7 (2017), 167-168.

57 Gamakharia, “Abkhazia/Georgia: Historical and Political Problems”, 43.

58 Marc Junge, Bernd Bonwetsch, Daniel Müller, "Georgien auf dem Weg”, Bolschewistische Ordnung in Georgien. Der Grosse Terror in einer kleinen kaukasischen Republik, hrsg von Marc Junge, Bernd Bonwetsch (Berlin, Boston: Walter de Gruyter GmbH, 2015), 325.

59 Gamakharia, "Abkhazia as the part of the democratic republic of Georgia", 401.
} 
Valimised igatahes toimusid ja uues Abhaasi Rahva Nõukogus saavutasid oodatult enamuse gruusia menševikud. Valimistel osales ja osutus valituks ka eestlane August Martin, Ülem-Linda eesti asunduse kooliõpetaja. Martin sai üle 600 hääle, mille hulgas oli ka mitte-eestlaste omi. ${ }^{60}$ Hiljem, olles juba Abhaasi Rahva Nõukogu liige, toetas Martin abhaaside rahvuslikke positsioone grusiinide anneksioonipoliitika vastu ja oli pinnuks silmas Gruusia poliitikutele. Oma mälestustes leiab ta, et see organ oli pelgalt Gruusia võimude käepikendus Abhaasias. ${ }^{61}$

Võimult tõrjutud abhaasid olid enne valimisi pöördunud Anton Denikini poole, kelle Vabatahtlik Armee oli juba septembris 1918 alustanud pealetungi, et tõrjuda grusiinid välja Sotši ringkonnast, mida nad pidasid osaks Kubanimaast ja seega Venemaa territooriumiks. ${ }^{62}$ Abhaasid teadsid küll, et Denikin nõudis Venemaa endiste piiride taastamist, kuid just seetõttu võis temast kasu olla grusiinide vastu. Abhaasi rahva nimel koostasid poliitikud petitsiooni, ${ }^{63}$ milles palusid Denikini abi võitluseks grusiinidega ja valimiste peatamiseks Abhaasias. Grusiinide Abhaasiast väljaajamise eest lubasid abhaaside esindajad petitsioonis ühendada Suhhumi ringkonna Venemaaga. Selle petitsiooniga pöördus Denikin 1. veebruaril 1919 ametlikult brittide poole, tehes ettepaneku muuta Suhhumi ringkond neutraaltsooniks, viia Gruusia väed Inguri jõe (Gruusia-Abhaasia piirijõgi) taha ja anda korra tagamine Abhaasias abhaaside endi kätte. Selleks ajaks oli Vabatahtlik Armee grusiinide käest tagasi võtnud juba suure osa Sotši ringkonnast. 6. veebruaril alustas Denikin oma plaani elluviimist, hõivates grusiinide käest esmalt Sotši ja seejärel Gagra ning jõudes 10. veebruariks Bzõbi jõe äärde, mis oli viimane tsaariaegse Sotši ringkonna piir. ${ }^{64}$ Denikin teatavasti ei tunnustanud Taga-Kaukaasia komissariaati ega selle otsust liita Gagra piirkond põhja pool Bzõbi jõge Suhhumi ringkonnaga. Nii läksid ka Gagra piirkonna eestlaste Salme ja Sulevi külad Vene valgete kontrolli alla. See seletab muuseas, miks Gagra piirkonna eestlased Abhaasi Rahva

\footnotetext{
60 Avgust Martin, "Vospominaniya ob Abhazii i ego uchastii v Abhazskom Narodnom Sovete", Abhaziya - dokumentȳ i materialȳ (1917-1921 g.g.) (Suhum, 2009), 274; EKLA 235.27.14, 1. 16. Truumann. Punaste päevade ajalugu Estonia asunduses Suhumi ringkonnas. 1917-1921.

61 Martin, "Vospominaniya", 288.

62 Marhuliya, “"Krasnaya” i “belaya” Rossiya protiv nezavisimosti Gruzii (1918g.)”, 119.

63 Kuulduste järgi oli selle koostajaks 1917. aastal Ajutise Valitsuse poolt ametisse pandud Suhhumi ringkonnakomitee juht Aleksander Šervašidze.

64 Zurab Papaskiri, Abhaziya. Istoriya bez fal'sifikatsii (Tbilisi: Isdatel'stvo Suhumskogo Gosudarstvennogo Universiteta, 2010), 202-203; Gamakharia, "Abkhazia as the part of the democratic republic of Georgia", 405; Firuz Kazemzade, Bor'ba za Zakavkaza (1917-1921) (Stokgol'm: CA\&CC PRESS, 2010), 226.
} 
Nõukogu valimistel ei osalenud ja August Martin Eesti Nõukogu kandidaadina vaatamata agitatsioonile sealsete eestlaste häältest ilma jäi:65 $d e$ facto ei kuulunud piirkond grusiinide poolt hõivatud Suhhumi ringkonna, vaid Denikini valgete käes oleva Sotši ringkonna koosseisu.

1919. aasta algul nautis Denikin suurt Entente'i riikide, eriti Suurbritannia toetust nii relvastuse kui ka muude ressursside näol. Kuna brittide eesmärk oli takistada enamlastevastaste jõudude omavahelist sõjategevust, vahendasid nad piirkonnas Denikini vastasseise Gruusiaga, aga ka näiteks Aserbaidžaaniga ${ }^{66}$ Grusiine ja Vene valgeid vahendades esitasid nad ettepaneku muuta Sotši ringkond neutraaltsooniks, kus rahuvalvet teostaksid britid. ${ }^{67}$ Denikin keeldus resoluutselt Sotšist lahkumast, ${ }^{68}$ sest see oli tema silmis Venemaa territoorium, millega ta polnud nõus kauplema. Nagu Denikini eelnevast memorandumist teame, soovis ta muuta neutraaltsooniks mitte Sotši, vaid Suhhumi ringkonna. ${ }^{69}$ Kuna edasised läbirääkimised tulemusi ei andnud, ei jäänud brittidel üle muud, kui viia vaidlusalusesse Gagra piirkonda oma sajameheline üksus. Tähtsaks küsimuseks edasistes läbirääkimistes sai demarkatsioonijoon kahe konfliktiosapoole vahel. Oluline oli see ka Abhaasia eestlaste seisukohast, kuna vaidlusalused piirid jooksid üsna Salme ja Sulevi külade lähedalt. Brittide üksus paigutati Bzõbi jõele, tsaariaegsele Sotši ringkonna piirile, mis asus mõnikümmend kilomeetrit eesti küladest ida pool. Mõlemalt osapoolelt võeti lubadus jõge mitte ületada. Lepe aga kaua ei pidanud, ${ }^{70}$ mis edasistes sündmustes tähendas Salmele ja Sulevile väga pingelist olukorda. Sellest kõneldakse täpsemalt allpool.

\section{Eesti asunikud Gruusia võimu all}

Edasistes sündmustes jäid Suhhumi ümbruse eesti külad Gruusia vägede kontrolli alla kuni enamlaste uue tulekuni 1921. aastal. See tagas teatava stabiilsuse, kui mitte arvestada sagedasi toidukraami ja hobuste rekvireerimisi grusiinide poolt. Põhjapoolsed Salme ja Sulevi käisid aga korduvalt

\footnotetext{
65 Martin, "Vospominaniya", 273; N. Kakurin, Kak srazhalasj revoljutsija. Tom 1. (Moskva, Leningrad: Gosudarstvennoje Izdateljstvo, 1925), 253; N. F. Bugai', "Predislovie", 9 .

66 N. F. Bugai', "Predislovie", 11.

67 Denikin, Ocherki russkoi smutŷ, 180.

68 Marhuliya, “"Krasnaya” i “belaya” Rossiya protiv nezavisimosti Gruzii (1918g.)”, 121.

69 Lakoba, "Ob issledovanii nemetskih uchenȳh...", 167; Gamakharia, "Abkhazia as the part of the democratic republic of Georgia", 406.

70 Kazemzade, Bor'ba za Zakavkaza (1917-1921), 228.
} 
käest kätte, mis tähendas, et tuli kogeda aktiivset lahingtegevust ja marodööritsemisi.

Vilja ja kariloomade rekvireerimisi olid külades varem läbi viinud ka enamlased, mis seletab asjaolu, et kui Gruusia väed suvel enamlastele peale tungisid, võtsid eestlased neid lahkelt vastu. ${ }^{71}$ Mainitakse ka mingrelite röövretki eestlaste juurde. ${ }^{72}$ Kristjan Truumannilt pärinevad teated võimuvahetusele järgnenud arveteõiendustest Estonia küla eestlaste vahel - vihavaenlasi antud grusiinidele enamlastena üles. ${ }^{73}$

Kohalike eestlaste mälestused annavad tunnistust ka pingete kohta abhaaside ja grusiinide vahel. Näiteks kui Gruusia kuulutas välja mobilisatsiooni, pöördusid Estonia küla eestlased selgituste saamiseks Abhaasia Rahva Nõukogu abhaasist esimehe Varlam Šervašidze poole, kes soovitas eestlastel grusiinide mobilisatsiooni ignoreerida - Abhaasia töötavat peagi välja omaenda militaareeskirja. Paari päeva pärast tuli aga grusiinide komissarilt uus käsk teenistusse tulla. Eestlased pöördusid uuesti Abhaasia Rahva Nõukogu poole ja vabastati mobilisatsioonist. ${ }^{74}$ Hiljem oli Suhhumi piirkonna eestlastel mobilisatsioonidest pääsemiseks abi kohalikest eesti organisatsioonidest ja Eesti konsulaarametnikest. 22. detsembrist 1918 Tiflisis tegutsenud Tiflisi Eesti Rahva Nõukogu seadis endale ülesandeks kaitsta piirkonna eestlaste huve ja täitis mõningatel andmetel kuni 25. septembrini 1920 ka Eesti riigi esindaja funktsiooni. ${ }^{75}$ Nõukogu andis välja Eesti passe, kuigi selleks puudus tegelikult Eesti Välisministeeriumi volitus ja seega juriidiline õigus, nagu tunnistas hiljem ka nõukogu esimees Johannes Kirkmann. ${ }^{76}$ Samas võisid ka sellised dokumendid kohalikele ametnikele ette näidates mõju avaldada, kui ametlikke passe veel polnud. 2. augustil 1919 otsustas Eesti valitsus asutada Tiflisis Eesti Vabariigi konsulaadi Kaukaasias elavate Eesti asunike huvide kaitsmiseks. Konsuli määramine aga venis ning alles 28. juulil 1920 määrati Kaukaasia Eesti konsulaaragent ametisse. Selleks sai Johannes Kirkmann, senine Tiflisi Eesti Rahva Nõukogu esimees ja kunagine Punase Lageda eesti küla kooliõpetaja. 25. septembril andis Tiflisi Eesti Rahva Nõukogu Eesti esindamise funktsioonid ja senise passide väljaandmise kohta käiva arhiivi üle

\footnotetext{
71 J. Kirkmann, "Mõnda Taga-Kaukaasia eestlaste elust", Postimees, 15.07.1920, 2.

72 EKLA 235.30.4, 1. 1: Tükike Ülem-Linda eesti asunduse ajaloost.

73 EKLA 235.27.14, 11: Kr. Truumann. Punaste päevade ajalugu Estonia asunduses Suhumi ringkonnas. 1917-1921.

$74 \quad$ Ibid., 1. 12-13.

75 ERA.957.11.896, 1. 182: Eesti Vabariigi konsulile Tiflisis 26.04.1921.

76 RA, ERA.957.11.896, 1. 58: Johannes Kirkmanni kiri 10.12.1920 Eesti Vabariigi välisministrile.
} 
uuele konsulaadile. Konsul hakkas välja andma uusi passe, kohati tunnistati kehtivaks ka senised Eesti Rahva Nõukogu välja antud passid. ${ }^{77} 1920$. aastal, kui Gruusia kuulutas välja uue mobilisatsiooni, pääsesid eestlased sellest tänu Eesti konsulile J. Kirkmannile, kes sõitis sügisel Suhhumi ja jagas soovijatele välja Eesti passid, mis vabastasid eestlased välismaalastena sõjaväeteenistusest. ${ }^{78}$

Suhhumi ümbruse eesti külade elanike käsi käis neil keerulistel sõjaaastatel siiski võrdlemisi hästi. 1920. aasta jaanuaris, kui Gruusia sõdis mitmel rindel, kirjutas Suhhumi külje all asunud väikese Kotkapesa eesti asunduse elanik Gustav Frisch, et Ülem-Lindas teenitakse hästi piima müügiga, millele oli nõudlust rohkem kui pakkumist. Estonia küla elanikud kauplesid tema sõnul peamiselt kapsa, kartuli ja mandariinidega ${ }^{79}$ Asunikud kurtsid küll, et sõja tõttu on ühendusepidamine Eestiga raskendatud, üksikuid kirju ja teateid kodumaalt saadi Inglismaa kaudu. ${ }^{80}$

Kindlasti keerulisem oli olukord teisel pool rinnet Psou jõe äärsetes Salmes ja Sulevis, mis järgnenud sündmuste käigus käisid korduvalt käest kätte. Ajal, mil Salme ja Sulevi jäid Gruusia võimu alla, vabastati mobilisatsioonist ka sealsed mehed, nii nagu olid vabastatud Suhhumi piirkonna eesti külade mehed. ${ }^{81}$ Eelnevast aga teame, et 1919. aasta alguses hõivas territooriumi valgete Vabatahtlik Armee.

\section{Eesti asunikud Vabatahtliku Armee võimu all}

Denikin pidi oma vallutuskavades arvestama oma peamiste liitlaste brittidega, kellega tema vaated Musta mere edasise saatuse suhtes päriselt ei kattunud. Kui Denikini plaan oli muuta neutraaltsooniks Suhhumi ringkond, siis britid nägid neutraaltsoonina pigem Sotši ringkonda koos Gagra piirkonnaga. Denikinist võib aru saada - grusiinide lahkumine tervest Abhaasiast oleks tugevdanud tema enda positsioone piirkonnas. Brittide siht oli aga üldisem: hoida grusiinid ja Vene valged üksteist nõrgestamast, et võidelda ühiselt enamlaste vastu. Nagu öeldud, paiknes alates veebruarist

77 EKLA 235.29.24, 1. 1: M. Mihkelson, Eesti Vabariigi Tiflisi konsulaadi ajalugu. 1921. 78 EKLA 235.27.14 1. 21: Kr. Truumann. Punaste päevade ajalugu Estonia asunduses Suhumi ringkonnas. 1917-1921.

79 Gustav Frisch, "Kiri Kaukaasiast”, Postimees: Hommikuväljaanne, 11.04.1920, 2.

80 RA, ERA.1583.1.294: Kirjavahetus Briti välisministeeriumi ja isikutega Taga-Kaukaasias elunevate eestlastega kontakti loomise asjus.

81 EKLA 235.29.6, l. 1: Lühikene ülevaade poliitiliste liikumiste kohta Sotshi ringkonnas Mustamere kubermangus 1918-st kuni 1921 aasta veebruari kuuni. 
1919 Bzõbi jõe ääres brittide sajameheline rahutagamisüksus, mis valvas, et kumbki, grusiinid ega Vene valged, jõge ei ületaks.

Kuidas suhtusid kohalikud eestlased Vabatahtliku Armee saabumisse? Nii enamlaste kui ka Gruusia menševike valitsemise ajal olid võimud läbi viinud toiduainete, hobuste ja vankrite rekvireerimisi, kuigi meeste mobilisatsioonist oli seni pääsetud. Nagu kirjutavad mitmed allikad, lootsid eestlased, et Denikini võim toob paremaid päevi ja stabiilsust. Julgust lisas ka sõna "vabatahtlikud" valgete armee nimes. Loodeti, et selline armee kedagi vägisi sõjaväkke ei võta. ${ }^{82} \mathrm{Ka}$ Denikin ise on oma mälestustes kirjutanud, et Sotši vallutamise järel 24. jaanuaril võtsid kohalikud elanikud valgeid suure rõõmuga vastu. ${ }^{83}$

Õige pea pidid aga pettuma nii Sotši elanikud kui ka Salme ja Sulevi eestlased. Algas Denikini armee vägivald - sagedased voorimineku käsud ja toidumoona rekvireerimised, mis viisid inimeste kannatuse katkemiseni. ${ }^{84}$ Meenutatakse, et kõige rohkem kannatasid just eesti külad, sest venelastel ei olnud endalgi midagi, veel vähem midagi ära anda. ${ }^{85}$

Valge terror Denikini poolt vallutatud territooriumidel on üldteada tõsiasi. On andmeid selle kohta, kuidas punaste käest vallutatud Maikopis lasksid valged juba esimestel päevadel pärast vallutust maha umbes 4000 inimest, kahe nädala pärast oli arv tõusnud juba 70oo-ni. Põhja-Osseetias lasti maha 1300 inimest, sealse Digori asula 12 ooo mägilasest lasti maha 2000 ja hävitati 113 hoonet. Kui suvel 1919 algas Denikini käes olevalt Kubanimaalt vilja väljavedu Entente'i riikidesse, tähendas see kohalikele elanikele suurt koormust vilja rekvireerimiste ja kõrgete maksude näol. Majanduslik rõhumine ja terror kutsusid esile kohalike elanike ülestõuse, mille mahasurumiseks oli Denikin sunnitud rinnetelt ära tooma mitmeid üksusi. ${ }^{86}$

Rudolf Summer, Punase Lageda kooliõpetaja, kes pääses salaja ühe laeva söeruumis Denikini annekteeritud territooriumilt välja, kirjutas, et eestlaste kui kõige usinamate asunike käsi käis neil aastatel raskelt. Denikini võimu all kannatati rohkemgi kui enamlaste käes. Valged seadsid

\footnotetext{
$82 \quad$ Ibid.

83 Denikin, Ocherki russkoi smutȳ, 180.

84 EKLA 235.29.6, 1. 1: Lühikene ülevaade poliitiliste liikumiste kohta Sotshi ringkonnas Mustamere kubermangus 1918-st kuni 1921 aasta veebruari kuuni; EAM 284.1.39, 2, 1. 25: Villem Ludvig. Sulevi partisaanid. Mälestused, Sulevi partisaanide organiseerimisest, nende võitlusest, 19. märtsist 1919 kuni 19. veebruarini 1921; Kirkmann, "Mõnda TagaKaukaasia eestlaste elust", 2.

85 EKLA 235.29.6, l. 1: Lühikene ülevaade poliitiliste liikumiste kohta Sotshi ringkonnas Mustamere kubermangus 1918-st kuni 1921 aasta veebruari kuuni.

86 N. F. Bugai', "Predislovie", 15-16.
} 
sisse tsaariaegse korra: taastati tolleaegsed vallavalitsused ja koosolekute pidamine keelati. Kui Gruusia valitsuse ajal lubati koolis õpetada emakeeles, siis Denikini võimu all seati koolides uuesti sisse vene õppekeel. Summer kirjutab, kuidas sõdurid küladesse toodi ja külaelanikud neid toitma pidid ${ }^{87}$ Ta toonitab kirjas Eesti Vabariigi esindajale Londonis Ants Piibule, et eriti raske on eestlaste olukord Sotši ja Adleri piirkonnas, ${ }^{88}$ kus asuvad Salme ja Sulevi. Märtsis 1919 kuulutas Denikin välja 15 aastakäigu meeste mobilisatsiooni, mis puudutas ka sealseid eestlasi. ${ }^{89}$ Denikini käskkiri teatas välikohtute organiseerimisest kohtadel - viivitamatult tuli hukata mobilisatsioonist kõrvalehoidjad..$^{90}$

Kuna piirkonnas oli rahuvalve eesmärgil sees briti üksus staabiga Gagras, hakkasid rahva seas levima kuuldused, et Inglismaa teeb Kaukaasiast oma asumaa. Abhaasia ajaloolane Stanislav Lakoba on juhtinud tähelepanu ka aastakümneid hiljem kirjanduses ringelnud kuulujutu maiguga väidetele, nagu oleks Abhaasias plaanitud võtta inglise keel koguni riigikeeleks. ${ }^{91}$ Tegelikult see nii muidugi ei olnud, kuid kohalikel elanikel puudus adekvaatne informatsioon brittide rollist piirkonnas. Eestlased, soovides brittide plaanides selgust saada, läksid Gagrasse asja lähemalt uurima. Villem Ludvik ja inglise keelt valdav Joosep Leht saabusid inglaste staapi, kus muidugi selgus, et mingist inglaste protektoraadist pole juttugi. Nagu Eestis oli 1918. aastal jõude, kes avaldasid brittidele soovi võtta Eesti Suurbritannia protektoraadi alla ja pidid pettuma, nii ka Abhaasias - britid tegid eesti asunike delegatsioonile ruttu selgeks, et Inglismaa tegutseb vaid rahuvalvajana grusiinide ja Vene valgete vahel. Ühtlasi andsid inglased eestlaste saadikutele teada, et Briti valitsus on vabatahtlikega heades suhetes, abistades neid enamlaste vastu. Eestlaste saadikud palusid inglastelt korra tagamist külades, mille kohta olevat inglaste staabist saadetud kohe ka raadiotelegramm inglaste valitsusele (või tõenäoliselt pigem inglise missioonile Kaukaasias). Saadikud olevat rõõmsalt koju sõitnud, kuid peagi selgus, et nende lootusi oli petetud. Britid ei võtnud valgete korrale

\footnotetext{
87 "Eesti asunikkudest Kaukaasias", Päevaleht, 13.04.1920, 2-3; RA, ERA.1583.1.294, slaid 4O: R. Summer. Revolutsiooni aeg Kaukasuse eesti asundustes 1917-1920.

88 RA, ERA.1583.1.294, slaid 12: R. Summeri kiri 23.02.1920 Eesti Vabariigi esindajale Londonis.

89 Võime, Tee uude ellu, 61.

90 Kikas, Remmelgas, "Kaukaasia Eesti asundused Vene kodusõja keerises", 89.

91 Vt Stanislav Lakoba, "Avgust Martin i éstonskie materialȳ o sobȳtiyah v Abhazii (1917-1921 gg.)”, Dialog vremen istoriya. Traditsii. Kul'tura. Almanah 2 (Suhum: AbIGI, 2018), 168-178 (169).
} 
kutsumiseks sisuliselt midagi ette. ${ }^{92}$ Eestlaste apelleerimine neutraliteedile inglastele mõju ei avaldanud.

Noortel eesti meestel ei jäänud muud üle kui põgeneda Suhhumi-lähedastesse eesti asundustesse, mis jäid Gruusia menševike annekteeritud territooriumile ja kuhu jäädi terveks suveks. Mindi mitme lainena. Pea igas talus oli Salme ja Sulevi küladest pärit põgenikke. ${ }^{93}$

Osa mehi lahkus, osa otsustas vastu hakata. Oli ka neid, kes küll soovisid lahkuda, kuid jäid asjaolude tõttu paigale. ${ }^{94}$ Villem Ludvik kirjeldab, kuidas Sulevi nooremad mehed kokku kogunesid ja otsustasid mobilisatsiooniga mitte kaasa minna. ${ }^{95} \mathrm{~J}$. Kirkmann on mobilisatsioonist hoidumise põhjusena välja toonud asjaolu, et Gagra piirkonna eesti asunikud pidasid ennast Eesti kodanikeks ega soovinud end Vene kodusõtta segada. ${ }^{96}$ Esialgu otsustati varjuda lähedal asuvates mägedes, kuid varuti ka sõjamoona, millele grusiinid lubasid lisa. Loomad aeti küladest mägedesse, vara peideti. ${ }^{97}$

Eestlastel ei jäänud muud üle kui valgete omavolile ja mobilisatsiooninõudele vastu hakata, kuigi see ähvardas nad valgete välikohtu ette saata. On põhjendamatu otsida sellisest vastuhakust klassivõitluse elemente ja enamlaste juhtivat rolli, nagu tehti nõukogude historiograafias. Salme ja Sulevi vahel asuval Neebo mäel toimus 21. märtsil 1919 koosolek, millest võttis osa umbes 50 saadikut 20 ümberkaudsest asundusest ja kus otsustati sõjariistus röövijatele vastu hakata. 23. märtsil toimus teinegi koosolek, nüüd juba umbes 700 mehe osavõtul - kogunesid piirkonna külade eestlased, venelased, moldaavlased ja grusiinid. V. Ludvik rõhutab, et kohalikud armeenlased koosolekul ei osalenud, kuigi nad moodustasid $75 \%$ piirkonna rahvastikust. ${ }^{98}$

Järgneval nädalal puhkesid Salme külas tulevahetused Vene valgete ja kohalike partisanide vahel, mida on erinevates mälestustes nimetatud tollastest lahingutest suurimaks. ${ }^{99}$ Andmed lahingu puhkemise asjaolude kohta on eri allikates mõneti erinevad. Ühe salmelase mälestuste põhjal

$92 \quad$ EAM 284.1.39, 1. 2, 25: Villem Ludvig. Sulevi partisanid.

93 August Martin, "Autobiograafia”, August Martini elu ja looming (Iisaku: Iisaku Muuseum), 34-65 (57); EKLA 235.27.14, 1. 28: Kr. Truumann. Punaste päevade ajalugu Estonia asunduses Suhumi ringkonnas. 1917-1921.

94 EKLA 235.29.8, 1. 3: Minu mälestused Salme mässu-sõjast.

95 EAM 284.1.39, 1. 2, 25: Villem Ludvig. Sulevi partisaanid. Mälestused, Sulevi partisaanide organiseerimisest, nende võitlusest, 19. märtsist 1919 kuni 19. veebruarini 1921. 96 Kirkmann, "Mõnda Taga-Kaukaasia eestlaste elust", 2.

97 EKLA 235.29.6, 1. 1: Lühikene ülevaade poliitiliste liikumiste kohta Sotshi ringkonnas Mustamere kubermangus 1918-st kuni 1921 aasta veebruari kuuni.

98 EAM 284.1.39, 1. 3: Villem Ludvig. Sulevi partisanid. Mälestused, Sulevi partisaanid.

99 Rahvusraamatukogu (edaspidi RR) 28.1.9, 1. 7: August Tinnerti mälestused oma isast Peeter Tinnertist ja oma elust Sulevi külas 19. saj. lõpus ja 20. saj. esimesel poolel. 1958. 
algas tulevahetus siis, kui külla saabusid sõdurid mobiliseerimisealisi mehi püüdma. Autor kirjutab pisut suureliselt: "Sellega siis oli sõda vabatahtlike valitsuse ja Salme riigi vahel kuulutatud." 100 Esialgu saatis edu kohalikke, seejärel aga tõid valged 29. märtsil kohale suurtükid ja kuulipildujad. Mitu tundi kestnud tõsise võitluse järel olid partisanid sunnitud taanduma.

Partisanide vastu saadetud valgete karistussalga ülem nõudis oma käskkirjas ülestõusnute juhtide väljaandmist, vastasel korral lubati külad maha põletada. Kuna partisanidelt vastust ei tulnud, hakati ähvardust täide viima. Salmesse tunginud karistussalk asus röövima, inimesi peksma, talusid põletama ja eestlaste vara riisuma. Lahkudes olnud igal denikinlasel midagi kaasa võetud. "Vankerid olid kuhjaga kõik sugu eestlaste vara täis," nagu kirjeldas üks külaelanik, kes oli päeval lahingu eest pakku läinud ja nüüd öösel tasahilju tagasi tuli. ${ }^{101}$ Esmalt nägi ta üht heina- ja loomaküüni "täiel hool" põlemas, Rannaküla (osa Salmest) paistis eemalt kui tulemeri. "Igale poole kuhu silm vaatas ei olnud muud kui tuli ja tuli, Jüri Reichenbachi talu kogu küünidega, August Tanveli maja, mille kõrval automobili rusud aurasivad, Kiseljovi maja, A. Kivi maja, Jüri Krönvalgi maja, küün ja kuur, Aleksander Tomassoni maja, ait ja kukurusi kuur, Taavet Pärnpuu maja, Gustav Krönströmi maja ja Mihkel Bloki maja." ${ }^{102}$

Kui mitu maja Salmes maha põletati, selles lähevad tunnistused lahku. Harald Kikas ja Jüri Remmelgas mainivad üheksat taluelamut koos kõrvalhoonetega, ${ }^{103}$ August Tinnerti mälestustes mainitakse üle 10 maja, ${ }^{104}$ Johannes Kirkmann kirjutab 19 mahapõletatud majast. ${ }^{105}$

Kohalike eestlaste mälestustest võib lugeda, et kuna ka valged olid kandnud suuri kaotusi, soovisid nad vastuhakkajatega läbirääkimisi. ${ }^{106}$ Tegelik põhjus oli see, et mitmel rindel üheaegselt võidelnud Denikin oli viinud osa oma vägesid Gruusia rindelt mujale - valgetel ei jätkunud siinsete vastuhakkajate jaoks lihtsalt ressursse. Enamlastega võideldi Doni oblastis ja liiguti üha põhja poole, eesmärgiga jõuda Moskvani ${ }^{107}$ Kaukaasias võideldi sel ajal n-ö säästurežiimil. Igatahes toimusidki 3. aprillil läbirääkimised

\footnotetext{
$100 \quad$ EKLA 235.29.8, 1. 5: Minu mälestused Salme mässu-sõjast.

101 Ibid., 1. 13.

102 Ibid., 1. 15.

103 Kikas, Remmelgas, "Kaukaasia eesti asundused Vene kodusõja keerises”, 91; vt ka EKLA 235.29.6, 1. 1: Lühikene ülevaade poliitiliste liikumiste kohta Sotshi ringkonnas Mustamere kubermangus 1918-st kuni 1921 aasta veebruari kuuni.

104 RR 28.1.9, 1. 7: August Tinnerti mälestused oma isast Peeter Tinnertist ja oma elust Sulevi külas 19. saj. lõpus ja 20. saj. esimesel poolel. 1958.

105 Kirkmann, "Mõnda Taga-Kaukaasia eestlaste elust", 2.

106 EAM 284.1.39, 1. 4: Villem Ludvig. Sulevi partisaanid, 4.

107 N. F. Bugai', "Predislovie", 11.
} 
- valged olid valmis loobuma kohalike talupoegade mobiliseerimisest, kuid nõudsid neilt vastutasuks relvade loovutamist. ${ }^{108}$

Denikin, kes soovis osa oma vägesid piirkonnast mujale paigutada, oli saanud brittidelt lubaduse mitte lasta grusiine üle Bzõbi jõe. Seda lubadust britid aga täita ei suutnud, grusiinid kasutasid hetke, ületasid 4. aprillil Bzõbi ja kuna valgetel sõdureid nappis, hõivasid kiiresti territooriumi kuni Mzõmta jõeni. ${ }^{109}$ Varsti nad küll taandusid ja jäid positsioonile Mehhadõri jõel, mis voolab mõned kilomeetrid Sulevist idas. Eestlastel oli jõele isegi oma nimi - Paruni jõgi. Miks peatusid grusiinid just Mehhadõril? Seda põhjendati kohati Gruusia nn loomuliku piiriga - see jooksvat mööda Kaukaasia peaahelikku. ${ }^{110}$ Olulisem oli tegelikult see, et piirkonna tähtsaim linn Gagra asub Bzõbi ja Mehhadõri vahel, mis nüüd jäi grusiinide kontrolli alla. Nii valged kui ka britid nõudsid küll grusiinide taandumist varasemale joonele Bzõbi jõe taga, kuid grusiinid keeldusid. ${ }^{111}$ Läbirääkimised takerdusid, grusiinid oma positsioonidelt ei taandunud ja jäid kuni 1920. aasta alguseni Mehhadõri äärde eesti külade vahetus läheduses. Denikin esitas jätkuvalt territoriaalseid nõudmisi: Gagra piirkond pidi liidetama Sotši ringkonnaga, nii nagu see oli olnud alates 1904. aastast. Kuid ka see nõue jäi tagajärjeta ja Gruusia väed Mehhadõrilt ei taandunud. Denikin võttis olukorra kokku sõnadega "ei sõda ega rahu". ${ }^{12}$

Kui 1919. aasta kevadel-suvel asus neutraaltsoon 7-10 versta laiuses Mehhadõri ja Psou jõgede vahelisel alal, ${ }_{, 13}^{113}$ tähendas see, et ka eestlaste Salme ja Sulevi jäid neutraaltsooni. Neutraaltsooni sisulist toimimist siiski ülehinnati, nagu ka brittide võimekust piirkonna neutraalsust garanteerida. Kui August Martin kirjutab oma mälestustes, et sõdivate poolte vahele asus Inglise missioon ja et Entente ei võinud lubada kommunistidele vaenulike

\footnotetext{
$108 \quad$ EAM 284.1.39, 1. 4: Villem Ludvig. Sulevi partisaanid, 4.

109 Mitukümmend kilomeetrit Bzõbist loodes, tänapäeval Vene Föderatsiooni Krasnodari krais.

110 Ekaterina Arhipova, Gosudarstvennȳe granitsȳ Rossii na Kavkaze: formirovanie i sovremennȳe problemȳ bezopastnosti (Volgograd, 2014), 95-96. Nn loomulike piiride mõiste oli tollal üldisemalt käibel. Eestiski leiti kahe maailmasõja vahelisel perioodil, et Eesti tollane idapiir polnud mingi juhuslik moodustis, vaid igivana loomulikel tingimustel põhinev raja. Vt Valter Lang, "Muinasmaastike avastamine", Maastik ja mälu. Pärandiloome arengujooni Eestis, koost Linda Kaljundi, Helen Sooväli-Sepping (Tallinn: TLÜ Kirjastus, 2014) 36-78 (59).

111 Gamakharia, "Abkhazia as the part of the democratic republic of Georgia", 406.

$112 \quad$ Ibid.

113 Beniamin Mailyan, "K voprosu o territorial'nom konflikte na Chernomorskom poberezhe Kavkaza (ijul' 1918-mă 1920g.)", Istoricheskoe prostranstvo: Problemȳ istorii stran SNG (Moskva, 2013), 174-207 (205); EKLA 235. 29.4, l. 1: W. Glück. Salme asunduse uuemast ajaloost. 1921.
} 
jõudude omavahelist sõdimist, ${ }^{114}$ siis on tal muidugi õigus. Samas Martini väide, et Salmest ja Sulevist moodustati erapooletu tsoon, mis ei kuulunud ei Vene valgetele ega Gruusiale, on õige vaid mööndustega - päriselt sealseid külasid sõdivad pooled rahule ei jätnud. Martin osundab ka Samuel Sommerit, kes olevat nimetanud seda maa-ala justkui iseseisvaks riigiks sellele vastavate tunnustega: territooriumi, rahva ja võimuga ${ }^{115}$ Ei Martin ega Sommer elanud 1919. aastal kohapeal ega olnud tegeliku eluga kursis. Õigus on pigem Villem Ludvikul Sulevist, kes kirjutab, et Sulevi küla jäi erinevate bandede tallermaaks terveks aastaks. ${ }^{116}$ Eriti rõhutatakse eestlaste mälestustes kohalike armeenlaste marodööritsemisi - ulatuslik teema, mis jääb suure mahu tõttu käesolevas artiklis käsitlemata. Olgu küll öeldud, et armeenlased olid liidus Denikiniga grusiinide vastu, mille põhjuseks oli eelkõige samal ajal toimunud sõda Gruusia ja Armeenia vahel.

Kohalik eestlane W. Glück mainib, et mais 1919 oli piirkond küll ametlikult neutraaltsooni osa, kuid valged võtsid selle teatud perioodiks enda kontrolli alla ja andsid Sulevi külast tuld grusiinide positsioonidele. ${ }^{117}$ Teine kohalik elanik August Tinnert kirjutab, kuidas neutraaltsooni korraldasid "röövretki" nii valged kui ka grusiinid. ${ }^{118}$ Ilmekas tõend selle kohta, et neutraaltsoon sisuliselt ei toiminud, oli Sulevi lahing, mis puhkes 17. mail, kui valged tulid Sulevisse toiduaineid rekvireerima. 17.-19. mail toimunud lahing valgete ja kohalike partisanide vahel lõppes viimaste võiduga. Villem Ludvik leiab, et võidus etendasid eriti olulist rolli just Sulevi mehed, kes moodustasid lahingus osalenud partisanidest umbes poole. Tegu oli osavate mägiküttidega, kes olid maailmasõjas saanud lisaks tubli lahingukarastuse. ${ }^{119}$

Kirjeldades denikinlaste metsikusi, mainib Rudolf Summer, et Denikini karistusväes oli ka paarkümmend eesti ohvitseri, kelle "nime ta ei julge nimetada". Oma osa saab Summerilt ka Samuel Sommer, eesti asunduste aktivist, keda Summer nimetab "ostetud hingeks" - Sommer käinud eesti asunduste elanikke Denikini armeega koostööle agiteerimas, põhjendades seda väitega, et "vennad kodumaal" võitlevat selle valitsusega käsikäes. Summeri kriitika on asjakohane: lühinägelik on võidelda üheskoos armeega, kelle lipukiri on "ühtne ja jagamatu Venemaa". Sommeri jt

\footnotetext{
$\overline{114}$ Martin, “Autobiogaafia”, 57.

115 Tsit. Martin, "Autobiograafia”, 57.

116 EAM 284.1.39, 1. 4: Villem Ludvig. Sulevi partisaanid.

117 EKLA 235.29.4, 1. 2: W. Glück. Salme asunduse uuemast ajaloost. 1921.

118 RR 28.1.9, 1. 8: August Tinnerti mälestused.

119 EAM 284.1.39, 1. 4-5, 29: Villem Ludvig. Sulevi partisaanid.
} 
agitatsioon põhjustanud kohalikes eesti asunikes, "kes unistasid oma Eestist ja kandsid soojemaid soovisi oma rindus vaba Eesti vastu", suurt segadust. ${ }^{120}$

1919. aasta suvel korraldasid valged veel väiksemaid rünnakuid, kuid valdavalt löödi need tagasi. Denikini üksused olid Põhja-Kaukaasias hõivatud nii enamlaste kui ka Mägivabariigi vastu võitlemisega. Mais 1919 andsid Denikini väed Mägivabariigi üksuste riismetele hävitavaid lööke. Samas tugevdasid 1919. aastal oma positsioone Põhja-Kaukaasias enamlased, kes pärast maailmasõja lõppu 1918. aasta sügisel said oma väed riigi läänepiiridelt lõunasse tõmmata. Sügiseks 1919 lõid enamlased tagasi nii Denikini kui ka ikka veel Mägivabariigile lojaalsed jõud. ${ }^{121}$ Enamlaste prioriteediks ei olnud siis veel Gruusia vallutamine, vaid Aserbaidžaan oma naftavarudega, kuhu Punaarmee oma väed nüüd paiskas. ${ }^{122}$

Kuna ägedam sõjategevus toimus mujal, tegutsesid nii Gruusia kui ka Denikini väed Abhaasias võrdlemisi loiult. Britid ei ilmutanud piirkonna rahustamiseks enam erilist initsiatiivi. Korduvalt esitasid nad küll grusiinidele nõudeid väed Mehhadõri jõelt Bzõbi jõeni tõmmata, kuid nüüd juba ilma erilise innukuseta. Oli näha, et konflikti likvideerimine britte enam eriti ei huvitanud. Septembris 1919 toimus Suurbritannia välispoliitikas pööre: valitsus jättis Venemaa piiririikidele vabaduse ise otsustada, kas sõlmida enamlastega rahu või mitte. Ühtlasi keelduti neid riike de jure tunnustamast - tunnustamise pidi brittide seisukoha järgi otsustama kas Pariisi rahukonverents või Rahvasteliit. Teame, et ka Balti riikidele, mis olid piiririikidena Gruusiaga võrdlemisi sarnases olukorras, keelduti edaspidi sõjalist abi osutamast. ${ }^{123}$ Suvel 1919, kui oli selge, et brittidest enam abi ei ole, üritasid grusiinid veenda itaallasi Gagra piirkonda (Bzõbi ja Mehhadõri jõgede vaheline ala) neutraaltsooni rajama, kuid neil polnud huvi oma üksusi sinna viia. ${ }^{124}$ Sügisel lahkusid Briti väed järk-järgult TagaKaukaasiast. ${ }^{125}$

\section{Roheliste armee}

Eesti meeste vastuhakud 1919. aasta kevadel-suvel on vaadeldavad uue jõu, roheliste armee formeerumise kontekstis. Erinevalt kohalikest

120 RA, ERA.1583.1.294, slaid 47: R. Summer. Revolutsiooni aeg Kaukasuse eesti asundustes 1917-1920.

$121 \quad$ King, Vabaduse viirastus, 181.

122 Arhipova, Gosudarstvennȳe granitsȳ Rossii na Kavkaze, 97.

123 Tarvel, Eesti rahva lugu, 208.

124 Gamakharia, "Abkhazia as the part of the democratic republic of Georgia", 407.

125 King, Vabaduse viirastus, 180. 
armeenlastest, kes toetasid Vene valgete Vabatahtlikku Armeed, koondus suur osa teistest kohalikest elanikest, sh eestlased, partisanide väkke, kelle eesmärk oli eelkõige kaitsta oma kodusid igat liiki relvaformeeringute ja marodööride rünnakute eest. Suve jooksul lisandus väkke ümbruskonnast üha uusi talupoegi ning ka ülejooksikuid valgete väest. Detsembri algul 1919 peeti grusiinide poolt annekteeritud Gagras Musta mere kubermangu talupoegade I kongress, mille osavõtjaskond oli rinnete tõttu võrdlemisi vähene. Kongressil võeti vastu resolutsioon Vabatahtliku Armee kahjurlikkusest ja valiti Musta mere kubermangu Vabastamise Komitee, kellele tehti ülesandeks Vabatahtlik Armee Musta mere kubermangust välja tõrjuda. ${ }^{126}$ Ühtlasi seati lähieesmärgiks Musta Mere Vabariigi moodustamine, kaugema eesmärgina nähti aga Venemaa Föderatiivset Vabariiki - asjaosaliste visioonis vabade rahvaste vaba liitu. ${ }^{127}$ Vabastamise Komitee koondas ühtse juhtimise alla erinevaid jõude, kes olid seni Musta mere rannikul ja metsastel mägedel hajutatult tegutsenud.

Kui eespool mainiti, et mõned autorid pidasid rohelisi Nõukogude võimu eest võitlejateks, siis nii see kindlasti polnud. Mööndustega võib küll väita, et näiteks põhjapoolsematele Kubanimaa rohelistele avaldasid teatavat mõju Jekaterinodari enamlased, kuid Musta mere kubermangu rohelisi enamlastega seostada ei saa, nagu kirjutas isegi Denikin. ${ }^{128}$ Poliitiliselt oli roheliste liikumine eelkõige esseeride mõju all. ${ }^{129}$ Esseerid küll koordineerisid roheliste tegevust, kuid see seltskond ei olnud ühtne. Olulise osa rohelistest moodustasid kohalikud talupojad, kelle eesmärk oli kaitsta oma kodusid ja kellel ei olnud selgeid poliitilisi hoiakuid. Osa lihtsalt pelgas punaste või valgete väkke mobiliseerimist - suure osa rohelistest moodustasid need, kes olid keeldunud kaasa minemast Denikini väljakuulutatud mobilisatsiooniga 1919. aasta algul ja olid end seni varjanud mägedes või põgenenud rinde taha, nagu tegid paljud Salme ja Sulevi eestlased. Mitmed rohelised nimetasid end "metsavendadeks" ja elasid metsas. ${ }^{130}$ Pole imestada, et ka Salme ja Sulevi valgetele vastuhakkavaid talupoegi nimetatakse paljudes käsikirjalistes mälestustes "rohelisteks". Eestlaste mälestustest selgub, et sõjariistu, moona ja riideid said nad juba

\footnotetext{
$126 \quad$ EAM 284.1.39, 1. 29: Villem Ludvig. Sulevi partisaanid.

127 Aleksandr Cherkasov, Anvar Mamadaliev, "Krest'yanskoe opolchenie Komiteta Osvobozhdeniya Chernomorskoŭ gubernii (1919-1920 gg.)", Istoriya i istoriki v kontekste vremeni, 8 (2011), 22-39 (24).

128 Denikin, Ocherki russkoi smutȳ, 198.

129 Auskii, Kazaki (Sankt-Peterburg: Neva, 2001), 368.

130 Smele, The Russian civil wars 1916-1926, 138; Bullock, Vene kodusõda 1918-1922, 25-26; RA, ERA.1583.1.294, slaid 45: R. Summer. Revolutsiooni aeg Kaukasuse eesti asundustes 1917-1920.
} 
1919. aastal Gruusia rahvaväelt, ${ }^{131}$ mis on kooskõlas teiste allikatega ${ }^{132}$ ja ka igati mõistetav - võideldi ju peamiselt grusiinidega sõjajalal olevate Vene valgete vastu. 27.-28. jaanuaril 1920 toimunud järjekordsest Sulevi lahingust kirjutab Villem Ludvik üheselt kui roheliste rinde võidukast aktsioonist, märkides ühtlasi, et kohalikud eestlased lõid aktiivselt kaasa ka järgnenud pealetungis valgetele Tuapse ja Sotši vahel. ${ }^{133}$ Sulevi lahing ja sellele järgnenud pealetung oli osa Vabastamise Komitee kavandatud ja läbiviidud ülestõusust, mis algas 27. jaanuari ööl vastu 28. jaanuari ümberkaudsetes asulates üheaegselt. Sihikule võeti valgete garnisonid. Tänu rünnaku ootamatusele ei suutnud valgekaartlased erilist vastupanu osutada ja roheliste armee liikus kiiresti edasi Sotši peale ning teistesse Sotši ringkonna asulatesse. Sotši hõivati 3. veebruaril. 13. veebruariks oli roheliste käes kogu Sotši ringkond, mis sai neile edasiste sõjaliste operatsioonide platsdarmiks. Musta mere kirderannikul jõuti isegi Novorossiiskini, kuid seda vallutada ei õnnestunud. ${ }^{134}$ Eestlane K. Milender kirjutab nn roheliste valitsusest Sotši ringkonnas 1920. aastal, mis taganud külades suhteliselt hea julgeoleku ja andis välja isegi oma rahatähti. Roheliste võim kestis küll vaid mõne kuu, kuni põhjast peale tungivad enamlased selle likvideerisid. ${ }^{135}$ Kui veel mais lootsid rohelised esseeridega eesotsas jõuda kokkuleppele põhjast peale tungiva Punaarmeega ja säilitada Sotši ringkonnas autonoomia, siis viimastel oli asjadest oma arusaam. Osa esseere arreteeriti, teised põgenesid. Pagenud üritasid küll veel organiseerida vastupanu, seekord juba enamlastele, kuid need katsed jäid edutuks. ${ }^{136}$

\section{Entente'i ja Vene valgete poliitika ning Moskva rahuleping 1920}

Enamlaste ja valgekaartlaste vastasseisus hakkas kaalukauss 1920. aasta algusest üha rohkem esimeste kasuks langema. Jaanuari algul 1920 vallutati valgete keskused Tsaritsõn ja Rostov. Valged olid sunnitud taanduma, kasakad deserteerusid massiliselt ja läksid koju oma peresid kaitsma. ${ }^{137}$ Märtsis õnnestus 30 ooo mehel Novorossiiskist Krimmi taanduda, 20 ooo langes aga vangi, kui Punaarmee Novorossiiski 26.-27. märtsil vallutas. Aprillis

$131 \quad$ EAM 284.1.39, 1. 6: Villem Ludvig. Sulevi partisaanid; EAM 284.1.25, 1. 10: Hildegard Hiioni kõne Sulevi küla 75. a. juubelil; RR 28.1.9, 1. 7: August Tinnerti mälestused.

132 Cherkasov, Mamadaliev, "Krest' janskoe opolchenie", 25.

133 EAM 284.1.39, 1. 6-7: Villem Ludvig. Sulevi partisanid.

134 Cherkasov, Mamadaliev, "Krest' janskoe opolchenie", 27-30; Auskii, Kazaki, 368.

135 EKLA 235.29.7, 1. 2-3: K. Milender. Salme ja Sulevi asunduste elust punastel aastatel.

136 Cherkasov, Mamadaliev, "Krest'janskoe opolchenie", 43jj.

137 Bullock, Vene kodusõda 1918-1922, 114. 
läks Denikin erru, vägede ülemjuhatuse võttis enda kanda baltisaksa juurtega Vene kindral parun Peter von Wrangell, nimetades ühtlasi senised väed ümber Vene Armeeks. ${ }^{138}$ Aprillis piirasid enamlased Sotši ümbruses sisse ja püüdsid kinni 60 ooo valget, samal ajal puhastati piirkond ka esseeride juhitud roheliste vägedest. ${ }^{139}$ Mais jõudsid punaarmeelased ka Salmesse ja Sulevisse, kuid suvel taandusid taas. ${ }^{140}$ Valged aga enam endast suurt sõjalist jõudu ei kujutanud. Alanud üleüldises valgete taganemises kannatasid taas kohalikud talupojad - nälginud ja räsitud sõdurid võtsid küladest kõik, mis võtta oli. Ka eesti külades algasid igapäevased tulevahetused valgekaartlaste röövsalkade ja kohalike talunike vahel. Olukorda leevendas pisut see, et mai alguses viisid Briti sõjalaevad osa valgekaartlasi ära Krimmi, osa põgenes ka Gruusiasse. ${ }^{141}$ Osa aga jätkas kohapeal marodööritsemist. "Endised rikkad eesti asunikud olid kerjusteks saanud," kirjutas J. Kirkmann küll ehk pisut liialdades, kuid lisas, et eestlased tahavad seetõttu kodumaale rännata. Kirkmann teadis, millest rääkis - Tiflisi Eesti Rahva Nõukogu esimehena oli ta juba varem välja kirjutanud Eesti Vabariigi välispasse ning pidanud Eestiga läbirääkimisi eestlaste kodumaale toimetamise asjus. Sel eesmärgil käis ta 1920. aasta suvel ka Eestis. ${ }^{142}$

Kui mõtleme neile heitlikele eesti asundusi räsinud sündmustele Abhaasias 1919. aastal ja 1920. aasta algul, oli osa asunike soov Eestisse asuda igati mõistetav. Oli ka neid, kes ei soovinud Eestisse ümber asuda mitte oma naha päästmiseks, vaid relv käes kodumaa eest võidelda. Rudolf Summer kirjutab: "Sadandatel oli suurem soov kodumaale jõuda ja seal ühiselt vaenlane väljapeksta." ${ }^{143}$ Jakob Lukats teatab, et Tiflisi eestlaste eestvõttel asutati Kaukaasias olevatest eesti sõjameestest eesti rood, kes pidi tulema täiesti sõjavalmina Eestisse, kodumaa iseseisvuse eest võitlejate ridadesse oma riiki kaitsma. Roodu asutamisest võtnud osa ka Suhhumi ringkonna eestlased, kes sel eesmärgil Tiflissi sõitsid. ${ }^{144}$ Musta mere ranna ja Taga-Kaukaasia Jaoskonna Eesti asunduste Büroo kirjas Eesti Vabariigi

\footnotetext{
$138 \quad$ N. Kakurin, Kak srazhalas' revoljutsiya, Tom 2 (Moskva, Leningrad: Gosudarstvennoye Izdatel'stvo, 1926), 367; N. F. Bugai', "Predislovie”, 18; Bullock, Vene kodusõda 1918-1922, 115.

139 Smele, The Russian civil wars 1916-1926, 140.

140 Võime, Tee uude ellu, 76.

141 EAM 284.1.25, l. 10: Hildegard Hiioni kõne Sulevi küla 75. a. juubelil; EAM 284.1.39,

1. 6: Villem Ludvig. Sulevi partisaanid.

142 Kirkmann, "Mõnda Taga-Kaukaasia eestlaste elust", 2; vt ka "Gruusia Eesti rahvanõukogu”, Postimees, 05.07.1920, 2.; EKLA 235.29.25, l. 1: M. Mihkelson, Tiflisi Eesti Rahva Nõukogu. 1921.

143 RA, ERA.1583.1.294, slaid 48: R. Summer. Revolutsiooni aeg Kaukasuse eesti asundustes 1917-1920.

144 Jakob Lukats, "Keset ilmakära. Eesti asunikkude elu Gruusias", 5.
} 
valitsusele seisab: "Eestimaa lapsed kaugel võõrsil tervitavad vaba kodumaad, tema valitsust ja sõjaväge ja soovivad jõudu raskes töös.” Büroo pidas 1919. aasta esimesel poolel läbirääkimisi Briti esindajatega Batumis eesti ja soome sõjaväelaste ja noormeeste kodumaale pääsemise asjus. Jutt käis umbes sajast mehest. ${ }^{145}$ Oli ka plaan moodustada eesti pataljon ja see kodumaale saata, kuid asi nurjus inglaste vastuseisu tõttu. ${ }^{16}$

Rahvuslikku innukust neil murrangulistel aastatel Abhaasia eestlastel igatahes jagus. Samuel Sommer on kirjutanud: "Võib isegi kinnitada, et asundustes on rahvuslik tunne palju elavam kui kodumaal ja kodumaa sündmusi jälgivad asunikud suure huviga."147

\section{Moskva rahuleping 1920}

Kuigi Denikin oli tunnustanud sõnades abhaaside iseseisvuspüüdlusi, pidas ta nii Sotši kui ka Suhhumi ringkonda Vene riigi osadeks, olles selles ühel meelel enamlastega. Viimased käsitasid mõlemat ringkonda, seega kogu Abhaasiat, Vene NSFV osadena. Ka Gruusiat ei soovinud kumbki jõud poliitiliselt tunnustada. Tegelikult ei kiirustanud keegi, ka mitte Entente'i riigid, Vene riigist eralduda püüdvaid väikerahvaste valitsusi tunnustama. Pariisi rahukonverentsil, mis algas 18. jaanuaril 1919 ja kus pidi kokku lepitama rahulepingu tingimustes, tunnustasid suurriigid küll Soome iseseisvust, teiste Venemaa piiririikide puhul leppisid aga 12. juunil 1919 nn Venemaa ülemvalitseja admiral Koltšaki lubadusega anda neile autonoomia. Viis päeva hiljem, 17. juunil 1919 esitasid Pariisi rahukonverentsi esimehele ühisdeklaratsiooni piirirahvaste valitsuste esindajad: lisaks Eestile veel Gruusia, Aserbaidžaan, Läti, Valgevene, Ukraina ja Põhja-Kaukaasia Mägivabariik. Deklareeriti, et Venemaa valitsuse seadused ei saa nende suveräänsete riikide puhul kehtida. Ühtlasi paluti rahukonverentsi nende riikide poliitilist iseseisvust viivitamatult tunnustada. ${ }^{148}$ Liitlaste ja Vene valgete reaktsioonid olid pigem jahedad. Eduard Laaman kirjutab, kuidas prantslased soovitanud piirirahvastel rääkida mitte üksnes enda huvidest, vaid arvestada ka liitlaste omadega ja seista vastu enamlastele. Grusiinid olid olnud prantslaste soovitusele kohe vastu, põhjendades, et piirirahvaid tahetakse panna

\footnotetext{
145 RA, ERA.1583.1.294, slaid 19: Mustamere ranna ja Tagakaukasia jaoskonna Eesti asunduste büroo kiri Eesti (Kodumaa) Walitsusele Tallinnas.

146 RA, ERA.1583.1.294, slaid 16: Ph. Kaljoti kiri Eesti konsulile Londonis.

147 RA, ERA 4402.1.38, 1. 13: Samuel Sommer. Väljarändamine ja eesti asundused endise Venemaa piirides.

148 Jaan Poska, Päevaraamat Pariisi rahukonverentsilt (Tallinn: Vaba Maa, 1921), 95.
} 
teostama Prantsusmaa Venemaa-poliitikat. Laaman selgitab, et Gruusia oligi eriolukorras, sest neil polnud karta niivõrd enamlasi kui Denikinit. ${ }^{149}$ Kohati ägedam ja kohati loium vastasseis Abhaasias ja selle piirialadel terve 1919. aasta jooksul on selle selgituse ilmekas tõend.

Kuid ka teised Vene valged olid piirirahvaste iseseisvuse vastu. Koltšaki välisministeeriumi memorandumis, mis anti 7. oktoobril Inglismaa sõjalise missiooni esindajale, seisis: Venemaa valitsus on endiselt seisukohal, et küsimust "äsja moodustatud Balti omavalitsuslikest üksustest", samuti Kaukaasia ja Taga-Kaukaasia territooriumidest ei saa lahendada ilma vene rahva nõusolekuta. ${ }^{150}$

Mõningate piiririikide soovile enamlastega rahu sõlmida olid liitlased selgelt vastu - oli ette näha, et kui selline samm ei põhjustakski otsest liitlaste blokaadi, siis Lääne abile sellised riigid enam loota ei saaks. Mis puutub näiteks Eestisse, siis rääkis välisminister ja Eesti delegatsiooni juht Pariisi rahukonverentsil Jaan Poska juulis rahukonverentsilt naastes, et enamlastega tuleb rahu sõlmida - vastasel korral ei jaksa Eesti aasta pärast enam sõdida Vene valgetega, kui need peaksid kallale tungima. ${ }^{151}$ Teiselt poolt jõudsid ka enamlased 1919. aasta suve jooksul otsusele, et neil pole jõudu võitluseks korraga nii Vene valgete kui ka piirirahvaste vastu - viimastega oleks seega vaja rahu sõlmida. ${ }^{152}$

Kolm kuud pärast Tartu rahulepingu sõlmimist Eesti ja Venemaa vahel kirjutati 7. mail 1920 alla ka Gruusia ja Venemaa vaheline Moskva rahuleping. Sellega tunnustas Nõukogude Venemaa Gruusia Demokraatliku Vabariigi iseseisvust. Põhjused olid muidugi pragmaatilised - Venemaa jaoks oli olukord vaatamata edule rinnetel üpris keeruline. Denikini armee oli küll lagunenud, kuid Krimmis püsisid enamlastevastane Vene valitsus ja kindral Wrangelli juhitud Vene Armee. Veebruaris 1919 oli puhkenud Nõukogude-Poola sõda, mis kestis ikka veel. Ka Gruusia jaoks oli olukord keeruline. Aprilli lõpus olid enamlased hõivanud Aserbaidžaani Demokraatliku Vabariigi. See likvideeriti ja kuulutati välja Aserbaidžaani NSV. Aprillis toimus San Remos konverents, kus Gruusia ja Armeenia delegatsioonid ei suutnud lahendada omavahelisi territoriaalseid vaidlusi. See jahutas Lääne suurriikide innukust kaitsta neid riike Nõukogude Venemaa

\footnotetext{
149 Eduard Laaman, Eesti välissaatkond ja Pariisi rahukonverents (Tallinn: Vaba Maa, 1921), 66-67.

150 Ilmjärv, "Balti-küsimus Pariisi rahukonverentsi eel ja ajal 1918-1920", 124.

151 Tarvel, Eesti rahva lugu, 204.

152 Laaman, Eesti välissaatkond, 68, 85.
} 
ja Türgi agressiooni eest. ${ }^{153}$ Seega oli Gruusia eluliselt huvitatud kompromissidest Nõukogude Venemaaga, samal ajal kui viimane soovis olukorras, kus vajati lisajõudusid võitluseks Poolaga, oma lõunapiiril hingetõmbeaega.

Moskva lepingu allakirjutamise ajaks olid Nõukogude ja Gruusia väed vastakuti Sotši ja Suhhumi ringkonna piirialal Mehhadõri jõel. Kuigi enne rahulepingu sõlmimist olid enamlased (nagu varem valgekaartlased) seisukohal, et ei Sotši ega Suhhumi ringkond (seega Abhaasia) pea kuuluma Gruusiale, sätestas Moskvas sõlmitud lepingu III artikkel piiri Nõukogude Venemaa ja Gruusia vahel Psou jõel. Nõukogude valitsus tegi sellega Gruusiale järeleandmisi, loovutades senise Musta mere kubermangu Sotši ringkonnast Psou ja Mehhadõri jõgede vahelise piirkonna Gruusiale. Seal asusid ka Salme ja Sulevi. Lepingu IV artikkel sätestas ka Suhhumi ringkonna kuulumise Gruusiale - seal paiknesid ülejäänud Abhaasia eesti külad. Sisuliselt tähendas see, et Nõukogude Venemaa tunnustas Gruusia kodusõjaaegseid anneksioone kogu Abhaasias. ${ }^{154}$

Moskva lepingu järgi markeeriti Nõukogude Venemaa - Gruusia piiril neutraalriba, mis ulatus viis versta mõlemale poole piiri ja hõlmas ka olulised mäekurud. Neutraaltsoon pidi püsima kuni 1. jaanuarini 1922 ja kummagi lepingupoole väed ei tohtinud seda hõivata ega rajada sinna oma kindlustusi. Täpse piiri pidi edaspidi kindlaks määrama mõlema riigi segakomisjon. Iseenesest polnud neutraaltsoonid piiridel riikide praktikas midagi erakordset, ka kolm kuud varem Eesti ja Venemaa vahel sõlmitud Tartu rahulepingu artikkel III punkt 2 oli sätestanud ajutise neutraaltsooni Eesti-Vene piiril kuni 1. jaanuarini 1922. Neutraaltsooni Psou jõe ääres jäid eestlaste külad Salme ja Sulevi, samuti elas eestlasi neutraaltsooni jäävates naaberasulates. Sulevi küla elanik Villem Ludvik kirjutab oma mälestustes, et tema koduküla piirkonnas pidid Nõukogude Vene väed taanduma Psou jõe taha, Gruusia menševike väed Mehhadõri jõe taha. ${ }^{155}$

\section{Eestlaste olukord ja kodakondsusküsimused}

Eesti Vabariigi väljakuulutamine avas Abhaasia eestlastele uued perspektiivid ja elavdas rahvuslikke meeleolusid. Nagu loeme Kristjan Truumanni

153 Z. Avalov, Nezavisimost' Gruzii v mezhdunarodnoĭ politike, 1918-1921 gg. (Paris, 1924), 270-276, cit. Andrew Andersen, "Moskovskiŭ dogovor 7 maya 1920 g. I gosudarstvennȳe granitsȳ Gruzii v 1920-21 gg.”. https://bit.ly/2PzRdZh (28.03.2021).

154 Sbornik dě̌stvujushchih dogovorov, soglasheniǔ i konventsĭ̌, zakljuchennȳh R.S.F.S.R. $s$ inostrannȳmi gosudarstvami. Vŷpusk I (Peterburg: Gosudarstvennoe Izdatel'stvo, 1922)), 27-28. https://ida.aule.ee/juriidika/Moskva_rahuleping.pdf.

155 EKLA 235.29.18, 1. 221: W. Ludvig, Sulevi asunduse ajalugu. 


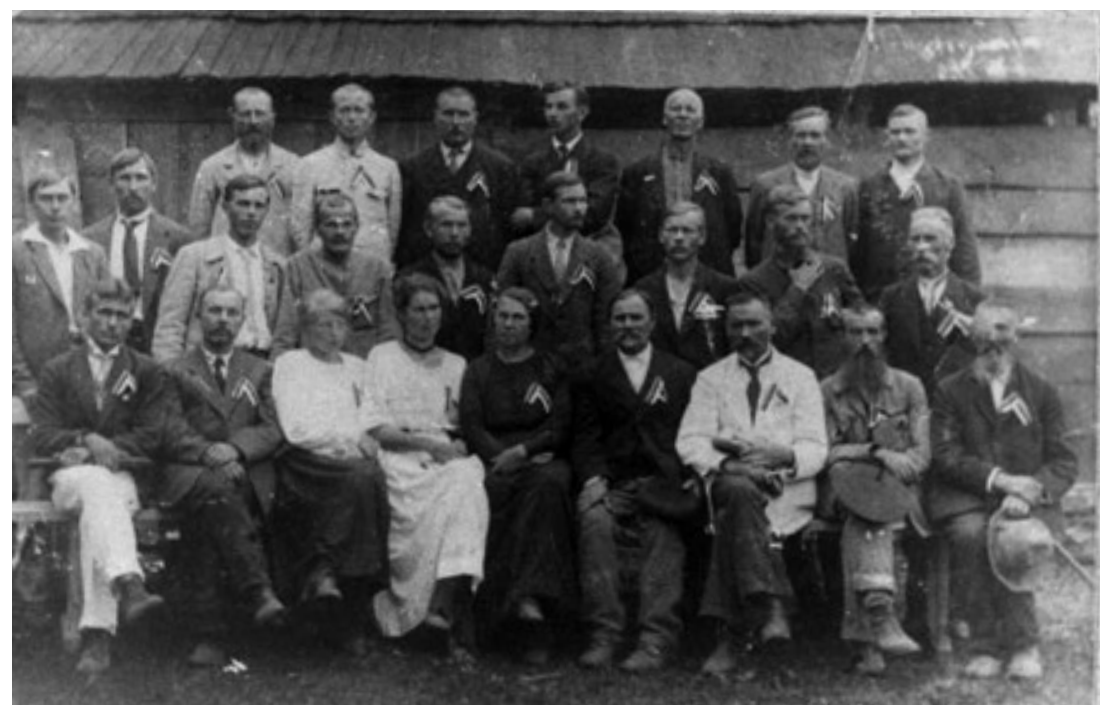

Joonis 2. Musta mere ranniku ja Taga-Kaukaasia eesti asunduste kongress Ülem-Linda asunduses, 1919. RA, EFA.505.0.154221

kirjeldustest, olid Estonia küla 1918. aasta jõulupeol koolitoas väljas Eesti lipud. Lisaks jutlust pidanud kösterkoolmeister Holbergile esines asunduste rahvusliku elu edendaja Samuel Sommer sütitava kõnega. ${ }^{156}$ 24. veebruaril 1921, kui üldine olukord Abhaasias oli äärmiselt ärev, tähistati Estonias Eesti Vabariigi aastapäeva hommikuse jumalateenistuse ja õhtuse peoga, kus Samuel Sommer pidas ettekande Eesti Vabariigi tekkimisest. ${ }^{157}$

Eesti oli nüüd iseseisev riik ja paljud omal ajal tsaaririigi avarustesse asunud eestlased pöörasid pilgud kodumaa poole. Värvika vinjeti esitab Gustav Frisch: "Mitmed väga jõukad mehed ütlevad lausa: "Kui ma ka kodumaal näljakäppa pean imema, kui ma ka kodumaal pops pean olema, tahan ma siiski vabas Eestis olla."'”158

Kuid rolli ei mänginud üksnes tõmbe-, vaid ka tõukefaktorid. Nii nagu Venemaal, oli ka Gruusia menševike võimu all oleval territooriumil toimunud maa natsionaliseerimine. Suhhumi ringkonnas, mis oli rikas tubakakasvatuse piirkond, natsionaliseeriti tubakaistandused, mille tagajärjel seiskus tubakatööstus. See sundis näiteks kohalikke kreeklasi, kes olid

$156 \quad$ EKLA 235.27.14, 1. 15: Kr. Truumann. Punaste päevade ajalugu Estonia asunduses Suhumi ringkonnas. 1917-1921.

157 Ibid., l. 32.

158 Frisch, "Kiri Kaukaasiast", 2. 
tegelenud aktiivselt tubakakasvatusega, Kreekasse välja rändama. Kannatas ka eestlaste tubakatootmine ja nagu kirjutab Jakob Lukats, soovisid tubakatootmisega tegelenud eestlased nüüd Eestisse rännata. ${ }^{159}$ Välja rändama ajendas ka suur põud Musta mere rannikul 1920. aasta suvel, mis tõi kaasa ikalduse. Iseäranis vilets oli maisi- ja kartulisaak..$^{160}$

Abhaasia eesti asunike seas oli palju neid, kes kaalusid Abhaasiast lahkumist ja Eestisse rändamist. Külades ringles kuuldusi Eestis ootavatest "pudrumägedest ja piimajõgedest" ning Eesti valitsuse plaanidest saata laevad asunikke ära tooma. Kuuldused olid kerged tekkima, sest asunikud polnud kodusõja segaduste tõttu pikemat aega Eestist ajalehti saanud. ${ }^{161}$ Ilma adekvaatse informatsioonita ei saanud aga nii suuri otsuseid nagu repatrieerumine ette võtta. 28. juunil 1920 oli Estonia rahvamajas koosolek, mida juhatas August Martin. Arutuse all oli küsimus, kas eestlastel on Gruusia riigis tulevikku. Martin tõi esile olulised muutused kohalikus elus: kui tsaariajal oli edendatud tööstust jm majandust, siis Gruusia iseseisvuse ajal on majandus alla käinud ning valitsus diskrimineerib teiste rahvuste esindajaid, mistõttu viimased on hakanud maalt lahkuma. Martin leidis, et kohalikud eestlased peaksid endale tingimata nii ruttu kui võimalik uut kodupaika otsima hakkama - kas Eestis, Ameerikas või Austraalias. Väljarändamist toetas ka Jakob Lukats, kes oli juba tsaariajal olnud kirglik eestlaste väljarännu õhutaja. Peale seda koosolekut tärkas asunikel Kristjan Truumanni sõnutsi tung Eestisse rännata. Informatsiooni hankimiseks ja sidemete taastamiseks kodumaaga võttis August Martin 1920. aasta augustis Abhaasia Rahva Nõukogust ${ }^{162}$ ja ühtlasi kohalikust eesti nõukogust puhkuse ning sõitis 20. augustil Tiflisi ja Bakuu kaudu Eestisse. Tagasi Abhaasiasse jõudis ta 3. detsembril. Nüüd, olles vahepeal tutvunud Eesti oludega, oli ta aga väljarännu suhtes hoopis skeptilisem. Ta andis asunikele nõu pigem paigale jääda - tema meelest olnuks suur kahju, kui rikkad asundused maha jäetaks ja läbi segadustes vaevleva Venemaa rännataks. Argumendina tõi ta ka välja, et põllumehel oleks Eestis raske tühjalt kohalt alustada. ${ }^{163}$ Arvestama pidi ka sellega, et paljudel oli lihtsalt hirm läbi kodusõjast pulbitseva Venemaa reisida. Kaaluti võimalusi jõuda

159 Jakob Lukats, "Keset ilma kära”, Postimees, 20.05.1921, 5-6.

160 Gustav Frisch, "Kirjad Kaukaasiast”, Hommikune Postimees, 26.10.1920, 2-3.

161 EKLA 235.27.14, 1. 20: Kr. Truumann. Punaste päevade ajalugu Estonia asunduses Suhumi ringkonnas.

162 Abhaasi Rahva Nõukogu nimetus alates maist 1919.

163 EKLA 235.27.14, 1. 20: Kr. Truumann. Punaste päevade ajalugu Estonia asunduses Suhumi ringkonnas. 
Eestisse meritsi, kuid on teada, et kaubalaevad, millele eestlased üritasid kohta saada, ei võtnud soovijaid peale. ${ }^{164}$

Nagu eespool kirjeldatud, said kohalikud eestlased Eesti kodakondsustaotlusi sisse anda Tiflisis Eesti konsulaaresinduses. Konsul sõitis Tiflisist spetsiaalselt Suhhumi kohale, et korraldada kohalike eestlaste kodakondsusasju. On aga samuti teada, et suur osa Salme ja Sulevi eestlastest esitasid oma avaldused Moskva Kontroll-Opteerimiskomisjonile (KOK). Miks just sinna? Eesti konsulaat Gruusias (ega selle esindus Suhhumis) polnud kevadel ja suvel 1920 veel tegevust alustanud (konsulaat avati Tiflisis alles 1920. aasta juuli lõpus), küll aga ajas suvel ja sügisel ümbruskonnas paiknevate eestlaste opteerumisasju Sotšis tegutsenud Eesti Komitee esindaja Peeter Litter. Ta ei vahendanud KOK-ile mitte üksnes Psou jõe paremkaldal, seega Nõukogude Venemaal elanud eestlaste (nt Punase Lageda asunike) teadaandeid, vaid andis 1920. aasta septembri lõpul neile üle ka paki Psou jõe vasakkaldal, seega Moskva lepingu järgselt Gruusia Demokraatliku Vabariigi piirides elanud eestlaste opteerimisteadaandeid. ${ }^{165}$

Tsaariajal olid nii Punase Lageda kui ka sealt mõnekümne kilomeetri kaugusel asunud Salme ja Sulevi kuulunud just Sotši ringkonda. Seega oli Sotši olnud ringkonna keskus nii Punase Lageda kui ka Salme ja Sulevi eestlastele, kujundades mentaalset topograafiat ja ilmselt ka identiteeti kui lõunapoolsete eesti asunduste elanikke kutsuti "Suhhumi eestlasteks", siis põhjapoolsete omasid "Sotši eestlasteks". ${ }^{166}$ Vahepealsed rindejooned kodusõja päevil ja nüüdne ametlik riigipiir olid liiga värsked, et harjumuspärast mentaalset topograafiat inimeste mälust kustutada. On seega loogiline, et ka Salme ja Sulevi eestlased pöördusid just Peeter Litteri poole, kes oli ennast seni käsitanud kogu "Sotschi maakonnas Mustamere kubermangus asuvate Eestlaste volinikuna" ${ }^{167}$ Võimalik, et kodusõja tingimustes, kus ajakirjandus ei liikunud või liikus episoodiliselt, said Salme ja Sulevi eestlased just Peeter Litteri vahendusel teada, et 1920. aasta mais oli Moskvas loodud kontroll-opteerimiskomisjon, mis hakkas tegelema eestlaste kodakondsusküsimustega. Nagu öeldud, algas selline tegevus Tiflisi Eesti konsulaadis hiljem.

\footnotetext{
164 Frisch, "Kiri Kaukaasiast", 2.

165 Marju Luts-Sootak, Eero Medijainen, Helen Rohtmets-Aasa, Karin Visnapuu, Kristi Aule, Aastatel 1918-1940 opteerimise teel Eesti kodakondsuse omandamise küsimusi käsitlenud õiguse ja halduspraktika analüüs (Tartu: Tartu Ülikool, 2018), 52.

166 Nt M. J. Wunk, "Mälestused Suhumist", Postimees, 14.05.1914, 7.

167 RA, ERA.36.1.23, 1. 446: P. Litter Moskva Kontroll-opteerimise komisjoni esimehele 23.10.1920.
} 
Olukord oli külaelanike jaoks kindlasti segane. Villem Ludvik nimetab oma mälestustes neutraaltsooni alasid küll "eikellegimaaks", kuid annab ometi teada, et asju hakkas seal korraldama siiski Gruusia valitsus, kelle korraldusel nimetati Sulevi partisanide rood miilitsarooduks, küla komissar (kelleks oli Ludvik ise) ja miilitsaülem said palka Gruusia valitsuselt. Piirkond oli rahulepingu järgi demilitariseeritud, nõnda et kui külla hakkas saabuma punaste eest taanduvaid valgete salku, nõudsid Sulevis ametikandjateks määratud talunikud nende kohest lahkumist, et mitte erapooletuse rikkumise süüdistusteks põhjust anda. ${ }^{168} \mathrm{~K}$. Milender viitab samuti sellele, et kuigi eesti külad jäid neutraaltsooni, käsitati neid ikkagi Gruusiale kuuluvatena - piir avati Gruusia poole vabaks kauplemiseks, nii et sügisel 1920 saadi eesti külade peamise aiasaaduse kuivatatud ploomidega juba kaubelda. ${ }^{169}$

Kuna neutraalriba staatus oli segane ka Eesti ametikandjate jaoks, ei võtnud nad sealt saabunud opteerimisteadaandeid kohe menetlusse. Ka Eesti ajakirjanduses ilmus 1920. aastal teateid, et kuigi sealsed eestlased soovivad opteeruda, on see maariba neutraalsuse tõttu keeruline. ${ }^{170} 1921$. aasta alguseks oli Eesti pool jõudnud siiski põhimõttelise otsuseni - 11. jaanuaril 1921 saadeti Eestist Moskva Kontroll-Opteerimise Komisjonile neutraaltsoonis elavate eestlaste legitimeerimiseks passid ja paluti nende väljajagamiseks ametnik määrata. ${ }^{171} 1921$. aasta aprillis, kui enamlased olid Gruusia Demokraatliku Vabariigi juba annekteerinud, väljastas KOK napilt nädala jooksul kodakondsustunnistused paarisajale endises neutraalribas elanud eestlasele. ${ }^{172}$ Kuni selle ajani elasid kohalikud eestlased närvilises teadmatuses, kas neid käsitatakse Eesti Vabariigi kodanikena või mitte.

\section{Enamlaste pealetung ja Gruusia Demokraatliku Vabariigi likvideerimine}

Gruusia menševikud pidasid Moskva lepet endale oluliseks saavutuseks. Samas jättis strateegiliste mäekurude demilitariseerimise nõue nad kaitsetuks võimalike põhjast lähtuvate rünnakute vastu. Lepe nõudis ka enamlaste partei legaliseerimist Gruusias, seega võib nõustuda autoritega, kelle väitel tähendas Moskva leping grusiinidele tegelikult oksa saagimist, millel

\footnotetext{
$168 \quad$ EAM 284.1.39, 1. 6: Villem Ludvig. Sulevi partisanid.

169 EKLA 235.29.7, 1. 3: K. Milender. Salme ja Sulevi asunduste elust punastel aastatel.

170 "Eesti asunikkudest", Hommikune Postimees, o1.10.1920, 1.

171 RA, ERA.957.11.896, 1. 139: Moskva Kontroll-opteerimise komisjonile, 11.01.1921.

172 Luts-Sootak jt, Aastatel 1918-1940 opteerimise teel, 53.
} 
nad istusid. ${ }^{173}$ 28. novembril 1920 tungisid enamlased varem vallutatud Aserbaidžaani kaudu Armeeniasse ja 4. detsembril Jerevani. Niikaua, kui enamlased olid seotud Nõukogude-Poola sõjaga ja valgete riismetega Krimmis, võis elus püsida ka Gruusia Demokraatlik Vabariik. ${ }^{174}$ Enamlasi olid seni pidurdanud ka Gruusias resideerunud Briti väeüksused, kuid nüüd olid nad läinud. Viimasena lahkus Briti garnison Batumist juuli keskel 1920. ${ }^{175}$

Kui kindral Wrangelli armee riismed novembris 1920 Krimmist Konstantinoopolisse evakueerusid ja Nõukogude-Poola sõda oli lõpusirgel (see lõppes märtsis 1921), lahendasid enamlased ka tülika Gruusia küsimuse. Veebruaris 1921 organiseerisid nad Gruusias ülestõusu: sealsele töörahvale tulid "abi osutama" enamlaste 9. ja 11. armee. ${ }^{176}$ Kõigepealt sisenes Punaarmee Gruusiasse Armeeniast, peagi ka Aserbaidžaanist, seejärel põhja poolt. Olukorda kasutas ära ka Türgi, kes nõudis Gruusia vägede lahkumist kahest piiriregioonist, ${ }^{177} \mathrm{mis}$ olid Bresti rahulepinguga lubatud Türgile. Gruusia oli sisuliselt igast küljest sisse piiratud. Lisaks oli Gruusia armee võitlusinnukus kahanenud sisepoliitilistel põhjustel, eelkõige tuleb nimetada Gruusia menševike poolt läbi viidud natsionaliseerimisi ja majanduse üldist allakäiku.

Gruusia valitsus kuulutas veebruari lõpus 1921, kui punased olid asunud üldisele pealetungile, välja üldmobilisatsiooni. Mobiliseerida üritati ka eestlasi. Sellest perioodist on säilinud mitmeid mälestusi, mis vahendavad eestlaste dilemmasid. Teati, et kodusõjas on enamlased saavutanud edu valgete üle, on ennast kehtestanud teistes Taga-Kaukaasia vabariikides, samuti haaranud enda kätte Põhja-Kaukaasia ja liiguvad kiiresti Suhhumi poole. Eestlaste üldine hoiak oli mobilisatsioonist kõrvale hoida. Paljudel olid Eesti passid - Tiflisi Eesti konsulaat oli alates augustist 1920 võtnud Eestist pärit isikuid Eesti kodakondsusse, osa neist oli sõitnud Eestisse, kuid suurem osa jäänud paigale. ${ }^{178}$ Abhaasiasse jäänud eesti mehed ei teadnud nüüd, kas nende Eesti välispassid neid mobilisatsioonist vabastavad - või kui vabastavadki, kas siis ei või võimud eestlasi maalt välja saata. Kardeti röövimisi, nii kohalike mingrelite, taganevate Gruusia sõdurite kui ka pealetungivate enamlaste poolt. ${ }^{179}$ Estonia külast on teateid, mille kohaselt olid kõik sealsed eestlased järjekordse mobilisatsiooni ajaks Eesti Vabariigi

\footnotetext{
173 Nt Smele, The Russian civil wars 1916-1926, 146.

$174 \quad$ Ibid., 144-145.

175 Ibid., 142.

176 Arhipova, Gosudarstvennȳe granitsȳ Rossii na Kavkaze, 100.

177 King, Vabaduse viirastus, 182.

178 RA, ERA.957.11.896, l. 113: S. Paul Eesti Vabariigi Välisministeeriumile, 26.08.1921.

179 EKLA 235.30.4, 1. 1: Tükike Ülem-Linda eesti asunduse ajaloost.
} 
alamateks saanud ja esitasid palvekirja, et neid kui välismaa kodanikke ei mobiliseeritaks. Grusiinist sõjaväekomisjoni esimees eestlaste Eesti passe aga ei tunnistanud ja väitis, et kohalike elanikena tuleb eestlastel teenistusse asuda. ${ }^{180}$ Sellised olukorrad said tekkida seetõttu, et Eesti ja Gruusia vahel puudus leping kodakondsuse vahetamise kohta. Uuel Eesti konsulaaresindajal Tiflisis (ametis alates 1. detsembrist 1920) Sergei Paulil tuli 1921. aasta algul sõita ka Suhhumi kohale, et mobiliseerimisohus eestlaste õigusi kaitsta, mis, nagu tunnistab konsulaadi sekretär M. Mihkelson, läks ka korda. ${ }^{181}$

1921. aasta alguseks oli olukord Abhaasias aga muutunud veelgi keerulisemaks. Oli juttu Gruusia võimude mobilisatsioonikäskudest, mida nüüd, kui enamlaste väed üha lähenesid, ignoreeriti ka teistes eesti külades. Martin Bahman Alam-Lindast on vahendanud tolleaegseid sündmusi oma külast, kus leiti, et vastupanu enamlastele on nüüd juba mõttetu, ja otsustati Gruusia mobilisatsioonist kõrvale hoida, varjudes mitu nädalat metsas. ${ }^{182}$ Need, kes otsustasid mobilisatsiooniga kaasa minna, kuid kellel olid Eesti passid, lasti siiski koju tagasi. ${ }^{183}$

Edasi toimus kõik kiiresti. 4. märtsi varahommikul kuulsid ÜlemLinda elanikud Suhhumi poolt püssipaukude raginat. Linnast saabusid teated, et enamlaste eelsalgad on juba Suhhumist läbi sõitnud ja Gruusia väed on taganenud ilma lahinguta, poode rüüstates ja kõike võimalikku kaasa võttes. Palju rahvast lahkus linnast, terve päeva vooris neid kottide ja kompsudega ka Ülem-Lindast läbi. Mõne päeva pärast saabusid külla enamlased, nõudes hobuseid. Külaelanike esimesed muljed punasõduritest polnud just ülearu positiivsed - sõdurid tundusid neile oma käitumiselt ja iseloomult toored ja loomalikud. Üha uued enamlaste salgad voorisid läbi küla, nõudes söögikraami ja viina. Sõduritel, kes juba teistest küladest saadud viinast purjus, olid panged kaasas. Mõnest majapidamisest saadi kuni 10 pange viina ${ }^{184}$ Külainimesed hakkasid oma vara peitma, kaevasid maa sisse riideid, toitu ja teravilja ning istutasid augu kohale katteks

180 EKLA 235.27.14, 1. 32: Kr. Truumann. Punaste päevade ajalugu Estonia asunduses Suhumi ringkonnas. 1917-1921.

181 EKLA 235.29.24, l. 1: M. Mihkelson, Eesti Vabariigi Tiflisi konsulaadi ajalugu. 1921.

182 EAM 284.1.21, 1. 45-50: Amalie Kaevatsi kogutud andmed Alam-Linda küla ajaloost, seletusi Alam-Linda fotode juurde, vastused J. Nermani saadetud küsimustele. 1961.

183 EKLA 235.30.4, 1. 2: Tükike Ülem-Linda eesti asunduse ajaloost.

184 Ibid., 1.3. 


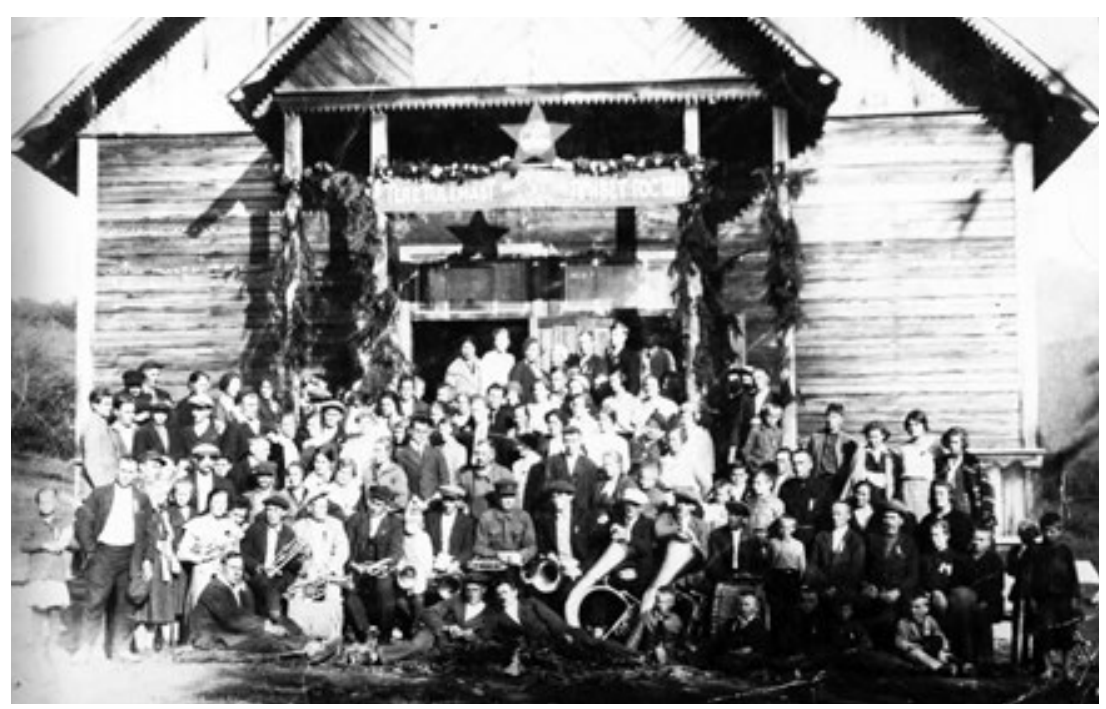

Joonis 3. Sulevi asunduse 50. juubeliaastapäeva tähistamine (?). RA, EFA.271.0.188576

puid. ${ }^{185}$ Estoniasse jõudsid enamlased 6. märtsil, nõudes toiduaineid, veini, hobuseid, vankreid ja hobustele heinu. ${ }^{186}$

Sama kiiresti kui arenesid sündmused Abhaasias, vaheldusid ka kohalike eestlaste meeleolud. Hästi peegeldab tollaseid siseheitlusi Salme küla elaniku K. Milenderi kirjutatu. Tõenäoliselt 1920. aastal kirjutas ta, et vaatamata viimaste aastate heitlustele on asunikud paigale jäänud ja loodetavasti pole neil vaja lahkuda ka edaspidi. ${ }^{187}$ Kui aga enamlased olid Abhaasias 1921. aastal võimule tulnud, väljendus K. Milender juba hoopis teisel toonil ja märkis, et kohalikud eestlased hakkasid nüüd lahkumise mõtteid heietama. Ise oli ta selleks hetkeks juba Abhaasiast lahkunud ja Moskvasse jõudnud. ${ }^{188}$ Kevadel 1921 ilmus Eesti ajakirjanduses teateid Salmest ja Sulevist, mis sisuliselt olid evakueerimispalved. ${ }^{189} 21$. aprillil 1921

185 EKLA 235.30.11, 1. 145: M. Rosenkron. Suhumi ja Suhumi ringkonna Eesti asunduste (Ül.-Linda ja Estonia) Chronika.

186 EKLA 235.27.14, 1. 34: Kr. Truumann. Punaste päevade ajalugu Estonia asunduses Suhumi ringkonnas. 1917-1921.

187 EKLA 235.30.9, 1. 1: K. Milender. Eesti asundused Mustamere kubermangus.

188 EKLA 235.29.7, 1. 3: K. Milender. Salme ja Sulevi asunduste elust punastel aastatel. 1921.

189 "Eesti asunikkude üliraske seisukord Kaukaasias", Postimees, 02.05.1921, 6. 
küsis Tiflisi Eesti konsulaat Eesti Valitsuselt rahalisi vahendeid eestlaste "reevakueerimiseks". ${ }^{190}$

Sellega seoses kerkib küsimus, kui palju oli Abhaasias tolleks ajaks Eesti Vabariigi kodanikke. Tiflisi Eesti konsulaat võttis 26. augustist 1920 kuni 26. augustini 1921 Eesti kodakondsusse 688 isikut, kellele väljastati kokku 365 passi (lisandusid pereliikmed). Sellest hulgast aga vaid 129 isikut (86 passiga) asus Eestisse ümber. Tiflisi Eesti konsulaadi andmeil elas 1921. aasta augusti lõpu seisuga Abhaasias ikka veel 387 Eesti kodanikku. ${ }^{191}$

Nüüd lisandus aga veel üks oluline aspekt: Gruusia ja Abhaasia vallutamisega oli enamlaste jaoks muutunud õigustühiseks ka 1920. aastal sõlmitud Moskva rahuleping Gruusia ja Nõukogude Venemaa vahel, mh ka seal sätestatud piirid. 31. märtsil 1921 moodustati Abhaasia NSV, mis oli formaalselt sõltumatu nii Gruusia NSV-st kui ka Vene Föderatsioonist Nõukogude Liitu polnud teadupärast veel moodustatud. 21. mail tunnustas Abhaasia NSV moodustamist ka Gruusia enamlaste valitsus. ${ }^{192}$ Abhaasia loodeosast lõikasid enamlased ära piirkonna Psou jõe vasakkaldal (Pilenkovo rajoon), kus asusid Salme ja Sulevi, ning liitsid selle Vene NFSV-ga. Oleks olnud ka muid võimalikke variante: esiteks referendumi korraldamine Abhaasias Venemaaga liitumise küsimuses, teiseks Abhaasia liitmine Põhja-Kaukaasiaga, kolmandaks Abhaasia NSV loomine koos Venemaa piiri nihutamisega Bzõbi jõeni. ${ }^{193}$ Nende teiste võimalustega võrreldes läks Abhaasial võrdlemisi hästi. Kaks eesti asustuspiirkonda Abhaasias - külad Suhhumi lähedal ja Psou ääres - jäid nüüd aga administratiivpiiride eri pooltele: esimesed Abhaasia NSV-s, teised Vene NFSV-s. 1929. aastal liideti Abhaasiast ära lõigatud Pilenkovo rajoon uuesti Abhaasiaga - küll vaid osaliselt, ${ }^{194}$ kuid Salme ja Sulevi kuulusid liidetava territooriumi hulka, seega leidsid end taas Abhaasia NSV koosseisust koos Suhhumi rajooni eesti küladega. Kohalike eestlaste identiteedi seisukohast oli aga administratiivpiiride nihutamine Nõukogude Liidu sees teisejärguline. Hoopis tähenduslikum oli, et Abhaasia eesti asundused olid nüüd ära lõigatud päritolumaast Eestist. Venemaa piirid tema servariikidega muutusid peagi

$190 \quad$ RA, ERA 957.6.196, 1. 10: Tifliisi konsulaadi 1921. a. tulude ja kulude kuuaruanded koos kirjavahetusega krediidi nõudmise küsimusis. 1921-1922.

191 RA, ERA.957.11.896, 1. 112: S. Pauli kiri Eesti Vabariigi Välisministeeriumile 26.08.1921; EKLA 235.29.23, 1. 1: Eesti Esitus Kaukasias.

192 Charlotte Hille, State Building and Conflict Resolution in the Caucasus (Leiden: Brill, 2010), 123.

193 Gamakharia, "Abkhazia as the part of the democratic republic of Georgia", 420.

194 Nikolaishvili, Tolordava, Sartania, Kutateladze, "Problems with the Drawing a State Border along the River Psou Section", 63. 
piirideks kahe ideoloogiliselt vastandliku maailma vahel. Asunike jaoks muutus kontaktide hoidmine omastega Eestis ja Eesti kultuuriväljal toimuvatest arengutest osasaamine järjest keerulisemaks.

\section{Kokkuvõte}

Esimene maailmasõda, oktoobripööre 1917. aastal ja sellele järgnenud kodusõda paiskasid Venemaa mitmeks aastaks sündmuste keerisesse, milles leidis oma lõpu tsaaririik ja sündis hulk uusi rahvusriike. Kuna Tsaari-Venemaa oli eelnenud kümnenditel teostanud ulatuslikku sisekolonisatsiooni, mille käigus sajad tuhanded inimesed olid asunud elama riigi teistesse piirkondadesse, avastasid nad end nüüd oma päritolumaadest äralõigatuna. Sisemigrantidest olid saanud välismigrandid. Abhaasias, kuhu 1880. aastatel oli tekkinud rida eesti asundusi, etendasid kodusõja sündmustes rolli Gruusia menševikud, Vene enamlased, Denikini Vabatahtlik Armee ja abhaasi rahvuslikud jõud. Kui Gruusia menševikke toetanud sakslased sõjast väljusid, hõivas nende koha inglaste sõjaline missioon, kes üritas koondada enamlastevastaseid jõude omavahelisele koostööle, kuid erilise eduta. Suhhumi ümbruse eesti külad Ülem- ja Alam-Linda, Estonia ja väheldane Kotkapesa jäid Gruusia okupatsioonivägede kontrollitud territooriumile praktiliselt kogu kodusõja ajaks, 1918. aasta esimesest poolest kuni 1921. aasta märtsini, mil piirkonna vallutas Punaarmee. Vaatamata pidevatele rekvireerimistele sõja vajaduste tarbeks möödus see periood nende külade jaoks suhteliselt rahulikult. Hoopis teine oli aga olukord põhjapoolsetes külades Salmes ja Sulevis, mis käisid aastatel 1918-21 pidevalt käest kätte: esmalt vallutasid selle enamlased, siis vaheldumisi Gruusia menševikud ja Denikini Vabatahtlik Armee, seejärel roheliste armee ja lõpuks taas Punaarmee. Mitmed lahingud Salme ja Sulevi külas ning nende ümbruses, valgete karistusaktsioonid ja marodööritsevate bandede rüüsteretked sundisid eestlasi kord koduküladest rinde taha teistesse eesti küladesse põgenema, kord vastuhakuks relvi haarama. Ühtlasi otsiti koostööd teiste piirkonna elanikest moodustatud relvastatud üksustega. Briti sõjalise missiooni nõudel rajatud neutraaltsoon jäi sisuliselt paberile ega suutnud piirkonnas rahu tagada.

Kui rääkida kohalike eestlaste suhtumisest erinevatesse vaenupooltesse, siis kõige teravama kriitika alla on erinevates mälestustes ja kirjapanekutes langenud valgete Vabatahtlik Armee. Gruusia Demokraatliku Vabariigi armee suhtes oldi suhteliselt neutraalsed, kuigi üritati nende mobilisatsioonidest kõrvale hiilida ja rekvireerimisi vältida. Salmes ja Sulevis, mis kannatasid valgete hirmutegude käes kõige enam, nähti grusiinides pigem 
liitlasi - siin kehtis ammune tõde: minu vaenlase vaenlane on minu sõber. Enamlaste erinevad võimuperioodid neil aastatel olid episoodilised ja eesti külade elanike enamus suhtus neisse deklaratiivselt küll neutraalselt, kuid sisuliselt kindlasti negatiivsemalt, kui on olnud tavaks kujutada nõukogudeaegsetes kirjutistes. Kõige positiivsem suhtumine sai osaks roheliste liikumisele ja nagu nägime, osaleti vabatahtlikult ka selle sõjalistes operatsioonides. Nõukogudeaegse ajalookirjutuse taotlus näidata kohalikke rohelisi enamlaste liitlastena pole kinnitust leidnud.

Neis rasketes oludes oli kohalike eestlaste jaoks olulise tähendusega Eesti Vabariigi väljakuulutamine 24. veebruaril 1918. Sellega tekkis uus dimensioon - Eesti muutus kohalike eestlaste jaoks kultuurilisest emamaast poliitiliseks garantiiks. Mitmel pool endise tsaaririigi territooriumil loodud Eesti komiteed ja nõukogud asusid välja andma Eesti Vabariigi kodanike isikutunnistusi, et päästa eestlasi kodusõjast punaste, valgete jt osapoolte vahel, nii ka Kaukaasias. Alates detsembrist 1918 Tiflisis tegutsenud Tiflisi Eesti Rahva Nõukogu andis välja Eesti passe - kuigi selleks ametlikku volitust polnud, aitasid ka sellised dokumendid kohalikke eestlasi kord edukamalt, kord vähem edukalt Gruusia mobilisatsioonist päästa. Ametlikult tegutses Eesti konsulaat Tiflisis alates juulist 1920, hiljem avati konsulaaresindus ka Suhhumis. Eesti passi omanike siirdumine Eestisse ei olnud erinevatel põhjustel siiski massiline. Märtsis 1921 vallutas Punaarmee Abhaasia ja Gruusia, kuid veel sama aasta augustis elas Abhaasias endiselt pea 400 Eesti kodakondsusse astunut. Suurem osa nii neist kui ka teistest Abhaasia eesti asunikest otsustas erinevatel põhjustel Abhaasiasse jääda. Ja kes olekski osanud siis ette näha töörahva paradiisi pigem põrgulikku tegelikkust - kõiki neid järjestikuseid repressioone, mis hiljem asundusi tabasid.

MärKsõNAD: Abhaasia; Kaukaasia; eesti asunikud; kodusõda; repatrieerumine AIVAR JÜrgenson on Tallinna Ülikooli ajaloo, arheoloogia ja kunstiajaloo keskuse vanemteadur.*

* Kirjavahetus: Ajaloo, arheoloogia ja kunstiajaloo keskus, Humanitaarteaduste instituut, Tallinna Ülikool, Narva mnt 25, 10120 Tallinn. E-post: aivarj@tlu.ee 


\section{Aвstract: Events of the Civil War in Estonian Settlements in Abkhazia 1918-21}

This article analyses events in the Estonian villages of Abkhazia during the Russian Civil War in 1918-21. The source material used is diverse. First, handwritten texts from two archives: the collection of Jakob Nerman preserved at the Estonian History Museum, and the collection of Samuel Sommer preserved at the Cultural History Archive of the Estonian Literary Museum. Both collections contain handwritten memoirs, chronicles, letters, etc. of Estonians in Abkhazia. In connection with diplomatic and consular matters, the author uses documents from the Estonian National Archives.

The introduction of these materials into circulation has been hindered so far for various reasons. During the Soviet era, objective analysis of the topic was impossible for ideological reasons. A discussion of the events of the Civil War took place in the Bolshevik Estonian press published in Russia in the 1930s, but it was conducted in the context of class struggle and distorted the facts. Forty years later, the historian Lembit Võime analysed the events of the Civil War in Caucasian Estonian settlements: first in an article published in 1973, and later in a monograph on Estonians in Abkhazia published in 1980. Like the authors of the 1930s, Võime emphasised that Estonian settlers fought for Soviet rule on the Black Sea coast in 191820. The author adhered to the Soviet-era tradition of describing almost all anti-Denikin movements in the Caucasus as revolutionary. Actually, most of the Estonian settlers of that time wanted to protect their homes and did not want to join the Russian Whites or Reds. There is no reason to interpret the so-called green movement on the Black Sea coast that many Estonians joined as pro-Soviet.

In 1974, an overview of the events of that time was published by the exiled Estonian authors Harald Kikas and Jüri Remmelgas, which used Võime's article from 1973 as a source. For political reasons, Estonians in exile could not use the materials in the Estonian archives. Hence, there is no study to date that uses all available material on the events of the Civil War in Estonian settlements in the Caucasus.

A number of Estonian settlements were formed in Abkhazia in the 1880s. During the Civil War from 1918 to 1921, Estonians came into contact with various military forces: Georgian Mensheviks, Russian Bolsheviks, the Volunteer Army of General Denikin, and Abkhaz national forces 
in cooperation with Abkhaz diaspora fighters. When the Germans, who supported the Georgian Mensheviks, withdrew from the war, a British military mission took their place and sought to mobilise anti-Bolshevik forces for cooperation, but without much success. The villages of Estonia (the village of that name in the Caucasus), Upper and Lower Linda near Sukhumi were located in territory that was controlled by the Georgian occupation forces for practically the whole period of the Civil War, from the first half of 1918 until March of 1921, when the Red Army occupied the area. Despite constant war requisitions, this period passed relatively quietly for these villages. But the situation was quite different in the villages of Salme and Sulevi in northern Abkhazia, which changed hands several times between 1918 and 1921: first the Bolsheviks, then the Georgian Mensheviks and the Voluntary Army, then the Green Army and finally the Red Army. Several battles in and around the villages of Salme and Sulevi, punitive actions carried out by the Whites, and raids conducted by marauding band of local Armenians who cooperated with the Russian Whites forced Estonians to flee from their villages, to shelter in other Estonian villages around Sukhum, and sometimes to seize weapons and seek cooperation with armed units formed by other inhabitants of the region. The neutral zone that was established at the request of the British military mission was unable to secure peace in the region.

In these difficult circumstances, the proclamation of the Republic of Estonia on 24 February 1918 had an important meaning for local Estonians. A new dimension had emerged, and Estonia had been transformed from the cultural motherland into a political guarantee for local Estonians. Estonian committees and councils were established in many parts of the territory of the former Czarist state to issue Estonian passports to save Estonians from the Civil War between the Reds, Whites, and others. This was also the case in the southern Caucasus. Starting in December of 1918, the Tiflis Estonian People's Council issued Estonian passports - although there was no official mandate for it, such documents also helped to exempt local Estonians from Georgia's mobilisations. Officially, the Estonian consul operated in Tiflis starting in July of 1920. A consular office was also opened later in Sukhum. However, for various reasons, there was no massive migration of Estonian passport holders to Estonia. In March of 1921, the Red Army conquered Abkhazia and Georgia, but in August of that same year, almost 400 persons who had acquired Estonian citizenship still lived in Abkhazia. For various reasons, despite Bolshevik rule, the majority of both these and other Abkhazian Estonian settlers decided to 
stay in Abkhazia. At that time, they could not yet foresee the repressions that later hit the settlements.

KeYwords: Abkhazia; Caucasus; Estonian diaspora; Russian Civil War; repatriation

AIVAR JÜrgenson is Senior Researcher at the Centre for History, Archaeology and Art History, University of Tallinn.*

* Correspondence: Ajaloo, arheoloogia ja kunstiajaloo keskus, Humanitaarteaduste instituut, Tallinna Ülikool, Narva mnt 25, 10120 Tallinn. E-mail: aivarj@tlu.ee 
